\title{
REVIEW ON OPTIMIZATION TECHNIQUES USED FOR DETERMINING MACHINING CONDITIONS TO GET EFFECTIVE TOOL LIFE AND SURFACE FINISH
}

\author{
KUMAR, S.
}

Abstract: Manufacturing industries are growing widely with development of various tools and techniques to manufacture products with desired quality and high accuracy. It has become extremely important for the manufacturing units to engineer and manufacture products with high quality and also eliminate the waste in production and processes. Reduction of scrap and rework help in achieving the desired target as extra material will be required. One of the most popularly used manufacturing processes is machining. It is the process of removing unwanted material to obtain the product of required shape, size and surface finish. Improper setting of cutting condition can cause damage to the workpiece and tool, hence it is important to investigate the performance of the machining parameters and study the effects of these parameters on the required response. Optimization of the machining parameters is an effective way to produce required quality product with negligible scrap generation. The present paper reviews the application of optimization techniques like Taguchi method, regression analysis, analysis of variance (ANOVA), response surface methodology, artificial neural network (ANN), fuzzy logic, and adaptive neuro fuzzy inference system (ANFIS) in predicting the influence of controlling factors on the required output and finding the optimal combination of machining parameters to obtain required response.

Key words: Manufacturing, Optimization, ANOVA, ANN, ANFIS
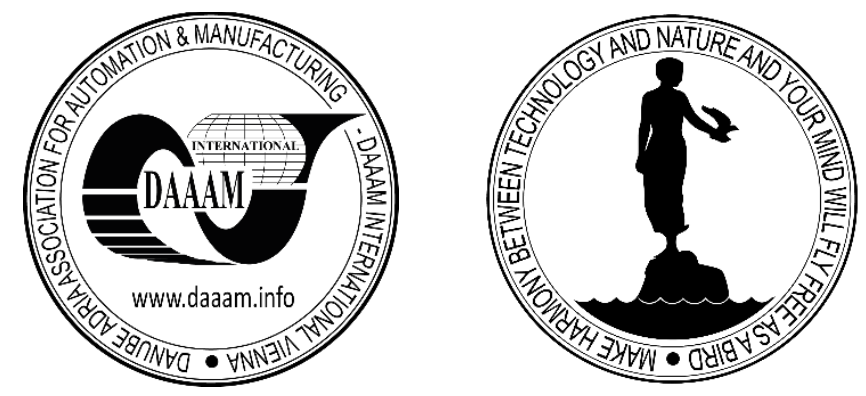

Authors' data: PhD. Kumar, S[atish]*; Symbiosis Institute of Technology, Baner 411007, Pune India satishkumar.vc@gmail.com

This Publication has to be referred as: Kumar, S[atish] (2017). Review on Optimization Techniques used for Determining Machining Conditions to get Effective Tool Life and Surface Finish, Chapter 19 in DAAAM International Scientific Book 2017, pp.235-264, B. Katalinic (Ed.), Published by DAAAM International, ISBN 9783-902734-12-9, ISSN 1726-9687, Vienna, Austria

DOI: $10.2507 /$ daaam.scibook.2017.19 
Kumar, S.: Review on Optimization Techniques used for Determining Machining C...

\section{Introduction}

Optimization is the method to achieve best possible result using the available resources effectively. In manufacturing industry, it is necessary to obtain optimum parameters for production of high quality products without generating scrap which causes economical loss to the firm. Various machining and geometrical parameters affect the quality of product manufactured. Some of the parameters that are varied to check for the most efficient combinations include feed rate, tool material, work piece material, cutting speed, tool nose radius, depth of cut etc.

The responses that are studied by varying these parameters are as follows:

1. Estimation surface finish.

2. Tool wear prediction

3. Tool life prediction

4. Cutting forces generated during manufacturing

5. Effect of vibration on tool

1. Surface finish refers to the surface texture that is attained after machining the workpiece. Selection of improper parameters may cause roughness and waviness on the surface of the product which leads to degradation of quality and rejection of the component. Various methods are employed to examine the effects of machining parameters on surface roughness, so the finished product has the required finish and shine without causing much of rework and scrap generation as surface roughness is one of the significant factor that has an effect on friction. Thus, it is necessary to optimize the process to ensure proper generation of surface finish.

2. Tool wear is a phenomenon where there is a loss of tool material while undergoing the manufacturing process causing failure of the tool. There are various types of tool wear like flank wear, crater wear, edge wear etc. caused due to abrasion, adhesion, diffusion, chemical decomposition and oxidation. Increase in cutting speed and temperature improper setting of machining parameters like feed rate, depth of cut and spindle speed are some of the causes of tool wear. Tool wear prediction helps in understanding the pattern and the parameters that have significant effect in wearing of tool. These parameters can be optimized to decrease the wear rate of the tool.

3. Tool life is the machining period which the tool undergoes before its failure. Tool life is greatly affected by machining parameters like feed rate, cutting speed and depth of cut. Tool wear too has a substantial effect on the tool life. Tool life prediction gives an idea about how the parameters contribute to the life of the tool. Drastic changes in some of the factors affect the tool life. Optimization of these parameters by applying various statistical techniques assists in estimating the tool life and establishing the optimum conditions.

4. Cutting force is the force that is generated when the tool machines the workpiece. It is affected by the cutting parameters like feed, depth of cut and cutting speed. Another important parameter that has a vital influence on cutting force is tool geometry. Cutting force and tool life are inversely proportional to each other. Proper lubrication is required to maintain the temperature change caused due to cutting forces. 
Optimization of the parameters helps estimating the ideal conditions to limit the cutting force.

5. Tool vibration is another phenomenon that can degrade the quality of products, produce noise while machining and shortens tool life. Improper machining conditions like high cutting speed or high feed rate are responsible for tool vibration. Analysis of the machining condition helps in understanding their role and contribution to the vibration while optimization helps in obtaining the best possible combination of the machining parameters to eliminate tool vibration.

\section{Introduction to the methods used for optimization}

\subsection{The Taguchi Method}

Taguchi method is a statistical approach to build robustness in the process during the experimental design stage. It was developed by Dr. Genichi Taguchi and employed in 1980 at AT\&T Bell laboratories. Dr. Taguchi introduced three of the important concepts to the world of statistics which are specific loss function, philosophy of off line control and innovation in design of experiments. Dr. Taguchi emphasized on reduction of unwanted parameters that would not add any value to the required output.

Specific loss function helps in investigating the deviation of performance from its target. For this purpose quality characteristics were specified such as smaller the better, nominal the better and larger the better depending upon nature of the output parameter to develop different quality function. The loss function is given as follows

$$
l=k E(y-t)^{2}
$$

Where

$1=$ quality loss function

$\mathrm{k}=$ quality loss coefficient

$\mathrm{E}=$ Expected value

$\mathrm{t}=$ Target value of $\mathrm{y}$

Thus, any difference from the required value and the measured value would indicate deviation from the target value which can also be considered as an indication to change the combination of input parameters to obtain required results. The objective for optimum design is to minimize the loss function. To eliminate variation, off line quality control is applied which is mostly used in manufacturing industry. It is divided into three stages.

The first stage is system design which a conceptual stage where the concept of product is created followed by the second stage known as the parameter design stage where the parameters are set and the detail design is developed. The last stage is the tolerance design stage where effect of process parameters on the output are studied and changes are made accordingly to reduce variations so that the output is in required limits. The main objective of tolerance design is to set the design parameters in acceptable level of variation. 
Kumar, S.: Review on Optimization Techniques used for Determining Machining C...

The experimental design stage has been greatly affected by Taguchi's method of orthogonal array. It helps in analyzing the combinations of input parameters by arranging them in orthogonal arrays depending upon the runs or the number of tests to be conducted, process parameters controlling the output parameter and the level at which they should be varied to obtain optimum results.

These fractional factorial experimental matrices are used to define the main effects using only few experimental runs. In Taguchi experiments the main effect and only two factor interactions are considered.

Another important concept in Taguchi method is signal to noise ratio. It originates from the communication system. It is expected that the input signal will produce output in exactly the same manner without any disturbances or variation. The disturbances are considered as noise in Taguchi method which is uncontrollable factors that occur during the experiments. One of the ideal ways for optimization is to maximize the signal to noise ratio.

The analysis of the Taguchi experimental data is done by analysis of variance (ANOVA) where the influence of considered process parameters are studied and significant parameter is estimated by the percentage contribution. Another data analysis method is the main effects chart and interaction chart, the main effect chart consists of a plot of average response at different level factor versus the factor level. On an interaction chart all factor level combinations for two factor interactions are displayed. The combinations of factors that produce optimal response are considered as optimum factors in Taguchi method.

The following literature review on application of Taguchi method in various manufacturing processes wherein optimum results in minimum number of experiments are obtained.

Surinder Kumar et al. (2013) adopted utility concept and Taguchi method to study the performance of machining parameters on turning of unidirectional glass fiber reinforced plastics with carbide $\mathrm{k} 10$ tool. The varying parameter selected were tool rake angle, feed rate, tool nose radius, depth of cut and cutting speed while the responses selected for were material removal rate and surface roughness. The experiments were conducted in varying cutting atmosphere like wet, cooled and dry.

The study states that optimization of one parameter lead to conflicting changes in other parameters; hence it was necessary to optimize all the parameters to obtain optimum results. Taguchi L18 orthogonal array, utility function and $\mathrm{S} / \mathrm{N}$ ratio were used to accomplish the multiresponse optimization. Utility concept is based on considering all the parameters for optimization. Utility function development involves creating a preference scale based on the optimal values of responses obtained from Taguchi method which were assigned weight based on preferences like smaller the better, nominal the better and higher the better, the entire data is analyzed accordingly. It was determined using analysis of variance that depth of cut had dominant influence on utility function followed by cutting speed and feed rate. The study concluded that integration of Taguchi method and utility function can be successfully applied to obtain optimum setting of the process parameters.

D. Philip Selvaraj et al.(2014) inspected the machining parameters on nitrogen alloyed duplex stainless steel for turning operation using $\mathrm{TiCN}$ and $\mathrm{TiC}$ coated carbide 
cutting tool inserts. Taguchi method was employed for optimization using L9 orthogonal array and signal to noise ratio. Analysis of variance was applied to examine the effect of feed rate, depth of cut and cutting speed on surface roughness, tool wear and cutting force. Depth of cut was maintained constant while feed rate and cutting speed were varied to collect the experimental data. The study reported that feed rate greatly affected the surface roughness and cutting force while cutting speed had a prevailing effect on tool wear. It was concluded that high tool wear was observed on rake surface than the edge of the cutting tool, also it was validated that high cutting speed led to critical flank wear, rake wear and notch wear.

Turgay Kıvak (2014) applied Taguchi method, analysis of variance (ANOVA) and regression analysis to predict flank wear and surface roughness of austenitic manganese steel also known as Hadfield steel using chemical vapor deposition (CVD) TiCN/A12O3-coated carbide inserts under dry milling conditions physical vapor deposition (PVD) TiAlN. The machining parameters selected were cutting speed, cutting tool and feed rate. Taguchi method was employed to design the experiment while $\mathrm{S} / \mathrm{N}$ ratio were used for optimization of machining conditions. Regression models were developed to estimate the surface roughness and tool wear. The ANOVA results showed that the feed rate is the most predominant factor affecting surface roughness while flank wear was significantly affected by cutting speed. The study also proposed that CVD coated that tools produced less flank wear compared to PVD coated tools.

Meenu Gupta, Surinder Kumar (2015) developed a model to predict optimum material removal rate and surface roughness for turning process of unidirectional glass fiber reinforced plastics composite with polycrystalline diamond tool by using Taguchi design of experiments, analysis of variance (ANOVA) and particle component analysis (PCA). The experimental data was obtained by means of Taguchi's L18 orthogonal array as a result of varying parameters like tool rake angle, cutting speed, feed rate, tool nose radius, depth of cut and cutting environment (dry, wet, cooled). The PCA method was employed to obtain a single objective function for multivariable optimization while ANOVA was employed to study the effect of process parameters on surface roughness and material removal rate. The study reported that material removal rate increases as all process parameters increase while the ANOVA results confirmed that the feed rate has the utmost influence on surface roughness.

Nilrudra Mandal et al. (2015) made an attempt to optimize the surface roughness of AISI 4340 steel using turning inserts of Zirconia Toughened Alumina (ZTA) by developing regression model and applying Taguchi method and ANOVA. The experiments were planned using L9 orthogonal array by varying parameters like depth of cut ,feed rate and cutting speed and the optimum machining conditions were achieved using S/N ratio. Regression models were used to estimate the response while ANOVA was adapted to investigate the influence of parameters on surface roughness. The study reported that cutting speed had the most substantial effect on surface roughness tailed by depth of cut.

Oussama Zerti et al. (2016) used Taguchi method to study the impact of feed rate, depth of cut, cutting edge angle, cutting insert nose radius and cutting speed on surface roughness, tangential force and cutting force under dry cutting conditions on AISI D3 
steel using mixed ceramic inserts. Analysis of variance was applied on $\mathrm{S} / \mathrm{N}$ ratios to get the dominant parameter while regression models were built to predict the responses by controlling the various parameters. Optimum machining parameters were obtained using Taguchi optimatisation approach. The study determined that feed rate has the most substantial effect on surface roughness and depth of cut is the most dominating parameter affecting tangential force and cutting force.

\subsection{Application of Taguchi method in manufacturing processes}

Based on the literature referred, Table 1 enlists the application of Taguchi method to design experiments using orthogonal array and to find the combination of process parameters to obtain optimal response by analyzing the signal to noise ratio for various in manufacturing processes.

\begin{tabular}{|c|c|c|c|c|c|}
\hline $\begin{array}{l}\mathbf{N} \\
\mathbf{0}\end{array}$ & Author & $\begin{array}{l}\text { Machining } \\
\text { parameter }\end{array}$ & process & $\begin{array}{c}\text { Machine } \\
\text { performance }\end{array}$ & Remarks \\
\hline 1 & $\begin{array}{l}\text { Surinder } \\
\text { Kumar et } \\
\text { al. }(2013)\end{array}$ & $\begin{array}{l}\text { tool rake angle, } \\
\text { feed rate, tool } \\
\text { nose radius, } \\
\text { depth of cut and } \\
\text { cutting speed }\end{array}$ & $\begin{array}{l}\text { Turnin } \\
\mathrm{g}\end{array}$ & $\begin{array}{l}\text { material } \\
\text { removal rate } \\
\text { and surface } \\
\text { roughness }\end{array}$ & $\begin{array}{l}\text { Integration of Taguchi method and utility } \\
\text { function approach was successful in } \\
\text { predicting the response accurately and } \\
\text { optimal conditions were determined. }\end{array}$ \\
\hline 2 & $\begin{array}{l}\text { D. Philip } \\
\text { Selvaraj et } \\
\text { al.(2014) }\end{array}$ & $\begin{array}{l}\text { feed rate, depth } \\
\text { of cut and } \\
\text { cutting speed }\end{array}$ & turning & $\begin{array}{l}\text { surface } \\
\text { roughness, tool } \\
\text { wear and } \\
\text { cutting force }\end{array}$ & $\begin{array}{l}\text { Cutting speed had a great influence on tool } \\
\text { wear and feed rate had dominating effect } \\
\text { on surface roughness and cutting force. } \\
\text { High tool wear was detected on rake } \\
\text { surface than on the cutting edge }\end{array}$ \\
\hline 3 & $\begin{array}{l}\text { Turgay } \\
\text { Kivak } \\
(2014)\end{array}$ & $\begin{array}{l}\text { Cutting speed, } \\
\text { cutting tool and } \\
\text { feed rate. }\end{array}$ & Milling & $\begin{array}{l}\text { flank wear and } \\
\text { surface } \\
\text { roughness }\end{array}$ & $\begin{array}{l}\text { Optimization using } \mathrm{S} / \mathrm{N} \text { ratio and provide } \\
\text { effective results. It was observed CVD } \\
\text { coated tool perform better than PVD } \\
\text { coated tool }\end{array}$ \\
\hline 4 & $\begin{array}{l}\text { Meenu } \\
\text { Gupta, } \\
\text { Surinder } \\
\text { Kumar } \\
(2015)\end{array}$ & $\begin{array}{l}\text { tool rake angle, } \\
\text { cutting speed, } \\
\text { feed rate, tool } \\
\text { nose radius, } \\
\text { depth of cut and } \\
\text { cutting } \\
\text { environment } \\
\text { (dry, wet, } \\
\text { cooled) }\end{array}$ & turning & $\begin{array}{l}\text { material } \\
\text { removal rate } \\
\text { and surface } \\
\text { roughness }\end{array}$ & $\begin{array}{l}\text { Optimized machining conditions were } \\
\text { found using Taguchi method and particle } \\
\text { component analysis. ANOVA results } \\
\text { depicted feed rate has the utmost influence } \\
\text { on surface roughness }\end{array}$ \\
\hline 5 & $\begin{array}{l}\text { Nilrudra } \\
\text { Mandal et } \\
\text { al. }(2015)\end{array}$ & $\begin{array}{l}\text { depth of cut } \\
\text {,feed rate and } \\
\text { cutting speed }\end{array}$ & turning & $\begin{array}{l}\text { surface } \\
\text { roughness }\end{array}$ & $\begin{array}{l}\text { It was observed that cutting speed had } \\
\text { considerable effect on surface roughness } \\
\text { followed by depth of cut }\end{array}$ \\
\hline 6 & $\begin{array}{l}\text { Oussama } \\
\text { Zerti et al. } \\
(2016)\end{array}$ & $\begin{array}{l}\text { feed rate, depth } \\
\text { of cut, cutting } \\
\text { edge angle, } \\
\text { cutting insert } \\
\text { nose radius and } \\
\text { cutting speed }\end{array}$ & turning & $\begin{array}{l}\text { surface } \\
\text { roughness, } \\
\text { tangential } \\
\text { force and } \\
\text { cutting force }\end{array}$ & $\begin{array}{l}\text { Analysis of } \mathrm{S} / \mathrm{N} \text { ratio showed that feed rate } \\
\text { has the most substantial effect on surface } \\
\text { roughness and depth of cut is the most } \\
\text { dominating parameter affecting tangential } \\
\text { force and cutting force. Taguchi method } \\
\text { was effective in obtaining optimal } \\
\text { parameters. }\end{array}$ \\
\hline
\end{tabular}

Tab. 1. Application of Taguchi Method 


\subsection{Response Surface methodology}

Response Surface Methodology is a collection of mathematical and statistical tools to find the optimum response influenced by several independent variables. RSM helps in building an empirical model by taking into consideration the input parameters and the required response. A function is developed based on the experimental data and regression analysis which is represented by the following equation,

$$
y=f(x 1, x 2, \ldots, x m)+\epsilon
$$

where

$$
\mathrm{y}=\text { response }
$$

$\mathrm{m}=$ number of independent variables or factors influencing response

$\mathrm{f}$ is the response surface function that which gives the relation between various independent variables like $\mathrm{x} 1$, $\mathrm{x} 2$ etc. and response

$\epsilon=$ error

The response can be represented as contour plots for better understanding of the effects of input parameters where contour lines represent the response pertaining to its respective input. The optimization depends on the nature of the response; like in some cases it is better if the response is larger. For example in case of tool life prediction combination of such input parameters would be selected that would give maximum tool life while in some cases it is preferred if response is smaller like in finding the optimum parameters for surface roughness and wear rate, the best combination of parameters would be those that would yield minimum surface roughness and wear rate respectively. For some cases it is better if it is achieved what is exactly required, in other words, nominal the best.

First order and second order models are employed depending upon the location of the current value of the response; if the value obtained is not close to the optimum then the first order model is applied where steepest ascent or descent method is used depending on the nature of response to move the value close to the optimum value. Once it is close to the optimum point second order model is used to find the accurate optimal response. The first order model when the function is linear is given as

$$
Y=\beta_{0}+\beta_{1} * X_{1}+\beta_{2} * X_{2}+\cdots+\beta_{j} * X_{j}
$$

Where,

$\beta=$ regression coefficient

$\mathrm{X}=$ main effect parameters

$\mathrm{Y}=$ response to be predicted

While the second order equation is used when interaction is considered between the variables and the function is quadratic and is given by, 
Kumar, S.: Review on Optimization Techniques used for Determining Machining C...

$$
\mathrm{Y}=\beta_{0}+\sum_{l=1}^{k} \beta_{l} * X_{l}+\sum_{l=1}^{k} \beta_{l l} * X_{l}^{2}+\sum_{l} \sum_{m} \beta_{l m} * X_{l} * X_{m}+\epsilon
$$

Where,

$\beta=$ regression coefficient

$\mathrm{X}=$ main effect parameter

$\mathrm{Y}=$ response to be predicted

X_(1 ) $\mathrm{X} \_\mathrm{m}=$ interaction between the parameters

$\epsilon=$ error

Another important method that has been applied in many research works is the desirability function approach. It is used in optimization of multi response surfaces. A desirability function is used to indicate the desirable values by assigning the value such as 0 and 1 for the most undesirable value and the most desirable value respectively. Individual desirability function are developed depending upon the optimization criteria which are similar to the nature of response mentioned earlier. Higher desirability indicates higher contentment in obtained values.

The following literature review would provide a broader view on the application of RSM in finding the optimum response value in various manufacturing processes.

Ashvin J. Makadia et al. (2013) applied design of experiments to investigate the effects of cutting parameters on AISI 40 steel with ceramic inserts for turning operations. The cutting parameters selected to examine the effect on surface roughness were feed rate, tool nose radius, cutting speed and depth of cut using Response Surface Methodology. A 3 level factorial design was planned and ANOVA was applied to study the effects of cutting parameters. The study reported that feed rate had the most influencing effect on surface roughness followed by tool nose radius and cutting speed. The interaction between tool nose radius and feed rate too had significant effect. Optimum machining conditions were obtained using response surface optimization.

S. Gopalakannan and T. Senthilvelan(2014) investigated the effect of gap voltage, pulse on and off time and pulse current on electrode wear ratio (EWR), surface roughness (SR) and material removal rate (MRR) for operations on Electrical Discharge Machine. The work piece was prepared by reinforcing SiC particles to Aluminum to obtain Aluminum 7075 (Al- $\mathrm{Zn}-\mathrm{Mg}-\mathrm{Cu}$ ) alloy. RSM and Analysis of variance were applied to examine the effect of parameters on metal removal rate, surface roughness and electrode wear rate. The results reported through RSM and ANOVA indicate that pulse current was the most influential parameter which had effect on all the responses while the optimal machining combinations were obtained using desirability approach. Figure 1 (a) and (b) shows the SEM micrograph of Silicon carbide particle distribution and the machined surface taken during the research work by the authors. 


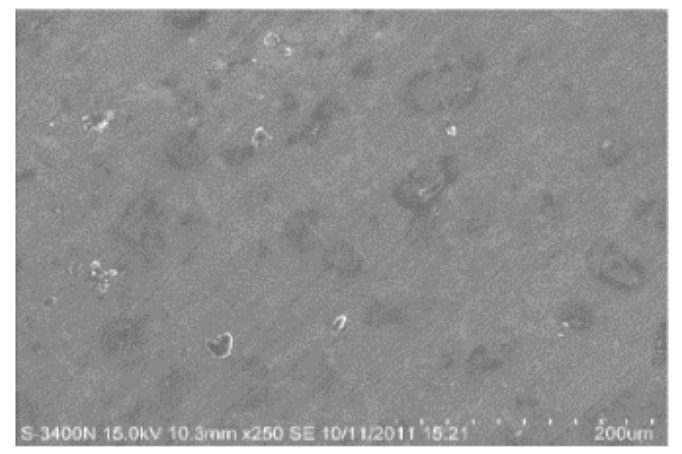

a)

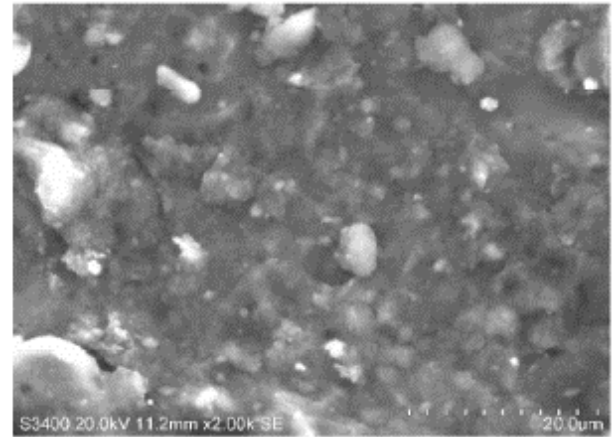

b)

Fig. 1. SEM micrograph of (a) SiC particle distribution and (b) crack of electrical discharged machined surface with dislodged $\mathrm{SiC}$ particles

Bhuvnesh Bhardwaj et al. (2014) developed two empirical model to predict surface roughness of EN 353 steel using carbide inserts for end milling operation. ANOVA was used for significance testing of both quadratic models while only one model was developed applying Box Cox transformation. The parameters selected were cutting speed, depth of cut, feed rate and tool nose radius. The results indicated that cutting speed was the most dominant factor followed by nose radius. The study concluded that model obtained using a Box Cox transformation has a better prediction capability than the other model.

M. Kamruzzaman et al. (2016) investigated the effect of feed rate, cutting speed, tool material, machining environment and work piece material on chip tool interface temperature by applying Artificial Neural Network techniques, Response surface methodology and ANOVA to determine the significant parameters. The workpiece material used were C-60, 17CrNiMo4, and 42CrMo4 steel alloys and standard carbide inserts like SNMG and SNMM were tools used while machining. Dry machining condition and high pressure coolant machining conditions were employed for investigation for interface temperature. The design of experiment was conducted through full factorial design while the response (tool chip interface temperature was predicted through RSM and ANN). According to ANOVA results cutting speed had a dominant effect on interface temperature followed by environment conditions. The study concluded that HPC assisted machining provides improved tool life. Figure 2 (a), (b) and (c) represent the flank wear at dry, wet and high pressure coolant condition respectively.

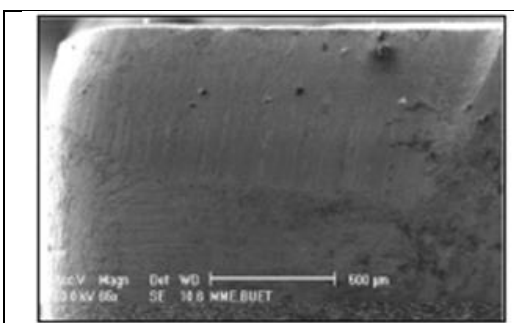

a)

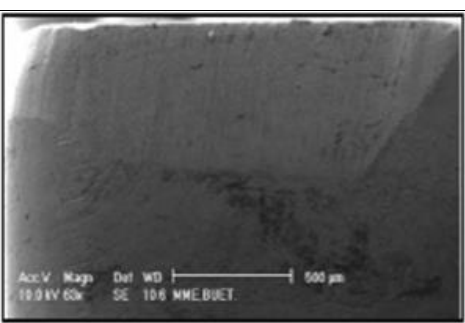

b)

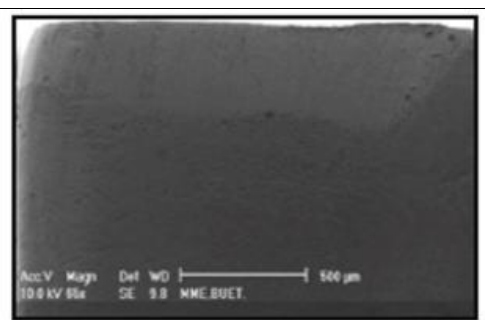

c)

Fig. 2 Images of the worn out edges of the carbide tool at $48 \mathrm{~min}$ in (a) dry (b) wet and (c) HPC condition 
K. Venkata Rao et al. (2016) applied, Artificial Neural network, Response Surface Methodology (RSM) and Support Vector Regression Method and ANOVA to study the effect of feed rate, spindle speed and tool nose radius on tool vibration and surface roughness to obtain optimum surface roughness and tool vibration by employing multi response optimization. The experiments conducted were used to find the relationship between input and output parameters using RSM, ANN and SVR for AISI 316 is a stainless steel using carbide coated tool inserts for boring operation. A feed forward algorithm was employed for ANN. The results for tool vibration showed that the cutting speed were significant parameter while the interaction between nose radius and feed rate substantially affected the surface roughness. The study concluded that ANN and SVR had higher predictability than Response Surface Methodology.

Priyabrata Sahoo et al. (2017) developed an empirical model using weighted principal component analysis (WPCA) and response surface methodology (RSM) to investigate the effect of feed rate, depth of cut and spindle speed on tool vibration and surface roughness on Aluminum

Alloy using coated carbide tool inserts in dry environment for turning process. Box-Behnken methodology was employed to RSM model was used to optimize the response that is influenced by various process parameters and WPCA was employed to achieve the better combination of process parameters to obtain optimum machining conditions. The results of Analysis of variance (ANOVA) showed that feed rate had great influence on surface roughness while the second order term of spindle speed was the dominant parameter in tool vibration. The study concluded that the interaction effect of feed rate and spindle speed played a vital role in tool vibration.

\subsection{Application of RSM in Manufacturing Processes}

In the referred research papers, response surface methodology was used to obtain optimum response by finding developing models to obtain optimum response. Table 2 lists the application of response surface methodology to depict optimum machining conditions for manufacturing processes.

\begin{tabular}{|c|c|c|c|c|c|}
\hline $\begin{array}{l}\mathbf{N} \\
\text { o. }\end{array}$ & Author & $\begin{array}{l}\text { Machining } \\
\text { Parameters }\end{array}$ & Process & $\begin{array}{c}\text { Machining } \\
\text { performance }\end{array}$ & Remarks \\
\hline 1 & $\begin{array}{ll}\text { Ashvin } & \text { J. } \\
\text { Makadia } & \text { et } \\
\text { al. (2013) } & \end{array}$ & $\begin{array}{l}\text { feed rate, tool } \\
\text { nose radius, } \\
\text { cutting speed } \\
\text { and depth of cut }\end{array}$ & Turning & $\begin{array}{l}\text { Surface } \\
\text { Roughness }\end{array}$ & $\begin{array}{l}\text { RSM precisely depicted the optimum } \\
\text { machining conditions. ANOVA results } \\
\text { suggested that feed rate had the most } \\
\text { influencing effect on surface roughness } \\
\text { followed by tool nose radius and cutting } \\
\text { speed. }\end{array}$ \\
\hline 2 & $\begin{array}{l}\text { S. } \\
\text { Gopalakann } \\
\text { an and T. } \\
\text { Senthilvelan } \\
\text { (2014) }\end{array}$ & $\begin{array}{l}\text { gap voltage, } \\
\text { pulse on and off } \\
\text { time and pulse } \\
\text { current }\end{array}$ & $\begin{array}{l}\text { Electrical } \\
\text { Discharg } \\
\mathrm{e} \\
\text { Machinin } \\
\mathrm{g}\end{array}$ & $\begin{array}{l}\text { metal removal } \\
\text { rate, surface } \\
\text { roughness and } \\
\text { electrode wear } \\
\text { rate }\end{array}$ & $\begin{array}{l}\text { Optimum machining conditions were } \\
\text { attained using desirability approach and } \\
\text { pulse rate was the dominating parameter } \\
\text { affecting all the responses }\end{array}$ \\
\hline 3 & $\begin{array}{l}\text { Bhuvnesh } \\
\text { Bhardwaj et } \\
\text { al. (2014) }\end{array}$ & $\begin{array}{l}\text { cutting speed, } \\
\text { depth of cut, } \\
\text { feed rate and } \\
\text { tool nose radius }\end{array}$ & $\begin{array}{l}\text { End } \\
\text { Milling }\end{array}$ & $\begin{array}{l}\text { surface } \\
\text { roughness }\end{array}$ & $\begin{array}{l}\text { Box Cox transformation was used to develop } \\
\text { one of the two models used in predicting the } \\
\text { response. The predictability of the box cox } \\
\text { transformation was higher than the other } \\
\text { model. }\end{array}$ \\
\hline
\end{tabular}




\begin{tabular}{|l|l|l|l|l|l|}
\hline 4 & $\begin{array}{l}\text { M. } \\
\text { Kamruzzam } \\
\text { an et al. } \\
(2016)\end{array}$ & $\begin{array}{l}\text { feed rate, } \\
\text { cutting speed, } \\
\text { tool material, } \\
\text { machining } \\
\text { environment } \\
\text { and work piece } \\
\text { material }\end{array}$ & Turning & $\begin{array}{l}\text { chip } \\
\text { interface } \\
\text { temperature }\end{array}$ & $\begin{array}{l}\text { ANOVA results suggested cutting speed had } \\
\text { a dominant effect on interface temperature } \\
\text { followed by environment conditions. Tool } \\
\text { life can be improved using high pressure } \\
\text { coolant. }\end{array}$ \\
\hline 5 & $\begin{array}{l}\text { K. Venkata } \\
\text { Rao et al. } \\
(2016)\end{array}$ & $\begin{array}{l}\text { feed rate, } \\
\text { spindle speed } \\
\text { and tool nose } \\
\text { radius }\end{array}$ & Boring & $\begin{array}{l}\text { tool vibration } \\
\text { and surface } \\
\text { foughness } \\
\text { fahoo et al. rate, depth } \\
\text { of cut and } \\
\text { spindle speed }\end{array}$ & $\begin{array}{l}\text { Turning } \\
\text { vector regression model was found to be } \\
\text { higher than response surface methodology. }\end{array}$ \\
\hline 6 & $\begin{array}{l}\text { Priyabrata } \\
\text { (2017) }\end{array}$ & $\begin{array}{l}\text { tool vibration } \\
\text { and surface } \\
\text { roughness }\end{array}$ & $\begin{array}{l}\text { RSM and WPCA were included for } \\
\text { optimization of process parameters. It was } \\
\text { observed that feed rate had great influence on } \\
\text { surface roughness while the second order } \\
\text { term of spindle speed was the dominant } \\
\text { parameter in tool vibration }\end{array}$ \\
\hline
\end{tabular}

Tab. 2. Application of RSM

\subsection{Regression Analysis}

Regression analysis is a statistical method to establish a relationship between variables. The most important parameter of regression model building is collection of data through any medium such as data obtained through designed experiment, through observation or through surveys. It is clearly evident that any regression analysis is only as good as the data that it is based on. Regression helps in converting a large amount of data collected into an equation, describing the relationship between input and output parameters. It is used in prediction and estimation of response variable and control of influencing variables to obtain the required output value.

There are two types of regression models that are widely used namely simple linear regression model and multi regression model. Simple regression model is used when only one control variable is affecting the response while multi regression models are used when more than one control variables affect the response.

Regression models are popularly used to estimate the mean response for a particular value of control variable x. Method of least squares is used in both the methods for estimating the regression coefficient using the data obtained by experiments. Method of least squares reduces the problem to linear algebra by means of minimizing the residuals of sum of squares of for the results of every equation and helps in finding an approximate solution for the system.

Analysis of variance (ANOVA) is used for significance testing of regression and also to find the dominant parameter by observing its percentage contribution. Confidence intervals are estimated for both types of regression models, these values are used to estimate the number of times the a value will be repeated if the same samples with similar size are selected for a particular number of time, in other words it estimates the frequency of the values that the regression coefficient can achieve for that particular sample and sample size.

Some of the other types of regression models used are quantile regression and random forest regression models. Anupam Agarwal et al.(2015) in their study of estimating the surface roughness of steel in the course of hard turning reported that 
Kumar, S.: Review on Optimization Techniques used for Determining Machining C...

quantile regression model helps in estimating the influence of variables on the response while random forest models help in ranking the significance of variables. The objective of quantile regression is to find the conditional median and the parameters or cut points that will highly affect the response, in other words it aims at finding the quantiles of the response. As quantile regression models are routed towards linear programming they can be solved using simplex method.

If the predictor variable and the response variable are related by a nonlinear function, such a model is known as nonlinear regression model. Application of method of least squares to nonlinear model results in nonlinear and complex solutions. One of the methods used for solving nonlinear regression analysis is random forest regression analysis. It is a statistical technique used for classification and regression. A regression tree is built with the target value of the regression model which aims at predicting the real value for the system at the leaf node. Every independent variable is substituted to fit the regression model to the target variable. Sum of squared error (SSE) is calculated for actual and predicted values and the parameter that gives minimum SSE is selected for leaf node and this process continues for data collected. Every leaf in the regression tree obtained after the complete procedure contains the output predicted in its preceding step which can be used to find the significance of every variable. The simple linear regression model is given as follows:

$$
Y=\beta_{0}+\beta_{1} * X+\epsilon
$$

Where,

$\mathrm{Y}=$ response to be predicted

$\mathrm{X}=$ independent variable

$\beta=$ regression coefficient

$\epsilon=$ error

Whereas the multiple linear regression model is given as follows:

$$
Y=\beta_{0}+\beta_{1} * X_{1}+\beta_{2} * X_{2}+\epsilon
$$

Where,

$\mathrm{Y}=$ response to be predicted

$\mathrm{X} 1$ and $\mathrm{X} 2=$ independent regression variables or controlling variables

$\beta=$ regression coefficient

$\epsilon=$ error $Y$

The following review deals with research work conducted in optimization of machining parameters for different responses like tool life, tool wear and surface roughness using regression analysis. It is evident that the most popularly used method for obtaining optimum response is multiple regression analysis. Analysis of variance is applied for significance testing of the parameters and for understanding the influence. 
V.S. Aigbodian et al. (2012) studied the wear behavior of recycled low density polyethylene (RLDE) reinforced with bagasse ash content under dry sliding conditions and also compared the performance of RLDE without any reinforcement. To study the effect on wear rate the varying parameter selected were applied load, sliding speed and sliding distance. Full factorial design and Taguchi method were applied to investigate the wear behavior. A regression model was built using the experimental data for prediction of wear rate by correlating to the wear rate with the controlling parameters. Analysis of variance (ANOVA) was employed to study the effect of every parameter on wear rate in terms of percentage composition. The study reported that RLDE with bagasse ash filled composite had higher wear resistance than the one without reinforcement while ANOVA results showed that applied load and sliding speed are the most significant parameters affecting the wear rate.

Anupam Agrawal et al. (2015) implemented multiple regression analysis, quantile regression analysis and random forest regression model to estimate the surface roughness of AISI 4340 steel using CBN cutting inserts by varying machining parameters such as depth of cut, feed rate and spindle speed. The results obtained from the regression models were compared to find the best fit for estimating the surface roughness for hard turning. The study reported that multiple regression model answered the question as to how the parameters affected the surface roughness while quantile regression analysis helped in understanding the influence of the variables on different surface roughness and Random forest model was used to rank the importance of variables. The results obtained from the three regression models suggested that the feed rate had the most dominating effect on surface roughness and the comparison result of multiple regression analysis and random forest regression analysis showed that the latter model had a better prediction capability than the former.

Samik Duttaa et al.(2015) implemented image texture analysis methods like GLCM (gray level co-occurrence matrix), VT (Voronoi tessellation) and DWT (discrete wavelet transform) on the turned surfaces of C-50 steel work piece using uncoated carbide inserts for tool wear prediction and tool condition monitoring. The image texture analysis with support vector regression was employed in the study to understand the prediction capability of the each method individually as well in combination. Images were obtained from the experimental setup for image analysis while support regression model was applied to predict the tool wear by using the results from image texture analyses and varying the parameters like depth of cut, spindle speed and feed rate. While each method depicted a different characteristic of machined surface, the study reported that the combination of all three image texture analysis methods along with support vector regression is best for predicting the tool wear.

Adel Taha Abbas et al. (2016) examined the effect of cutting speed, feed rate and depth of cut on surface roughness on high strength steel with carbide tools using ANOVA and regression analysis through DOE full factorial design. Factorial design was built using three independent variables with four levels of each factor. The results showed variation in surface roughness indicating minimum point among different machining conditions which was further verified using ANOVA and regression analysis. Multiple regression analysis and ANOVA results depicted that as feed rate 
Kumar, S.: Review on Optimization Techniques used for Determining Machining C...

increases the surface roughness also increases. The optimum machining conditions were obtained using multi objective optimization by minimizing surface roughness and maximizing metal removal rate. It is reported in this study that the feed rate has the most significant effect while the interaction between feed rate and depth of cut has a secondary effect on surface roughness. Figure 3 (a) and (b) represent the microscopic pictures of the machined surface at constant depth of cut, spindle speed and varying feed rate.

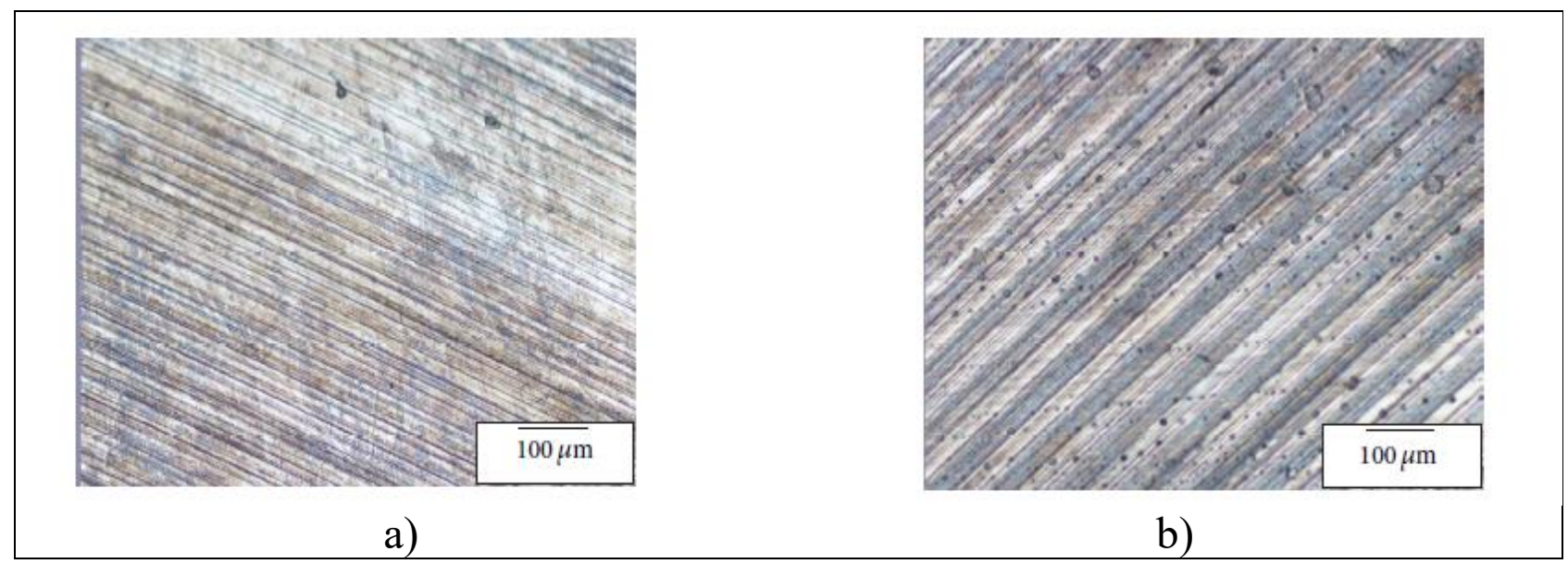

Fig. 3. Microscopic images of machined surface with depth of cut $0.5 \mathrm{~mm}$, spindle speed $=1250 \mathrm{rpm}$ and feed rate of (a) $50 \mathrm{~mm} / \mathrm{min}$ and (b) $125 \mathrm{~mm} / \mathrm{min}$

Nabeel H. Alharthi et al. (2017) compared the predicting capability of regression analysis and artificial neural network in estimating the surface roughness from face milling of Magnesium Alloy AZ 61 using carbide inserts. The experimental data was obtained by varying the machining parameters such as depth of cut, spindle speed and feed rate.

Multivariable regression analysis was employed for analyzing the multifactor data to estimate the surface roughness while five models of ANN were developed using the data acquired from experiments to obtain the best fit by changing the amount of neurons in the hidden layer.

The efficiency of ANN model was observed to be slightly more than regression model with coefficient of determination of $94.93 \%$ and $93.63 \%$ respectively while the optimum material removal rate conditions for minimum surface roughness were identified through multivariable optimization.

It was observed that higher feed rate led to higher surface roughness and poor surface finish owing to increased cutting forces and higher friction. Optical microscopy results depicted that feed rate has the most influencing effect on surface finish. Figure 4 (a) and (b) represent the machined surfaces of the machined surface at constant depth of cut, spindle speed and varying feed rate. 


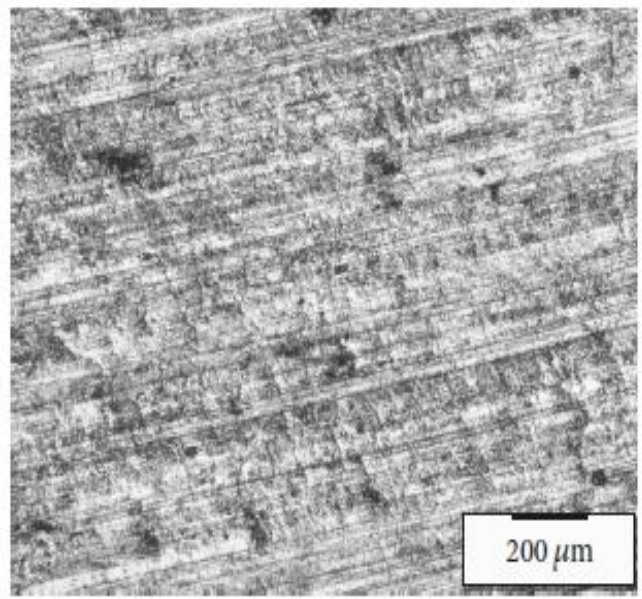

a)

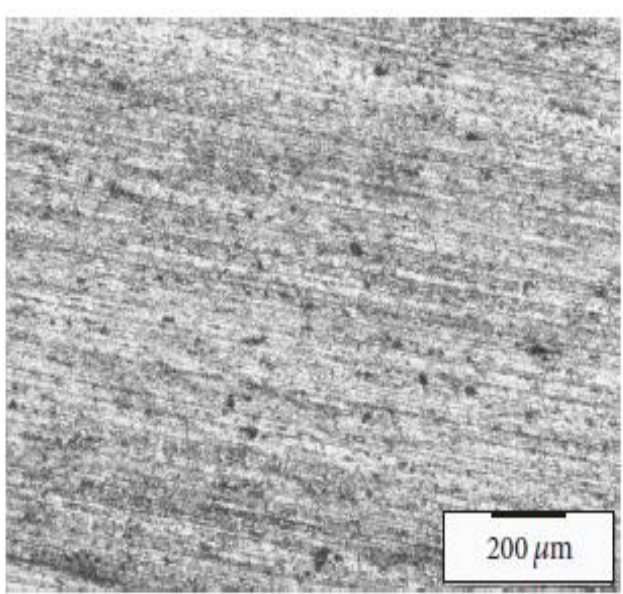

b)

Fig. 4. Machined surfaces at speed at depth of cut $0.5 \mathrm{~mm}$, speed at $500 \mathrm{rpm}$ (a) feed rate of $150 \mathrm{~mm} / \mathrm{min}$ and (b) $50 \mathrm{~mm} / \mathrm{min}$

S. Thirumalai Kumaran et al. (2017) performed abrasive water jet machining on unidirectional Carbon fiber-reinforced plastic (CFRP) and unidirectional CFRP with fabric woven surface for predicting surface roughness by varying parameters like jet speed, standoff distance and transverse speed using multivariable regression analysis model. Taguchi orthogonal array was developed from the experimental data while regression model was used for correlation of the machining parameters to predict response which is surface roughness in this case. They reported that the higher jet speed produced good surface finish while low transverse speed and standoff distance are also essential to obtain good surface finish. Jet speed was determined to be the most dominant parameter by ANOVA. The study reported that better surface finish is achieved in case of unidirectional CFRP with fabric woven surface.

\subsection{Application of Regression Analysis in Manufacturing Processes}

Table 3 lists the application of regression analysis in predicting response by developing models to relate input parameters and the response in various manufacturing process.

\begin{tabular}{|l|l|l|l|l|l|}
\hline No. & \multicolumn{1}{|c|}{ Author } & Parameters & \multicolumn{1}{|c|}{ Process } & $\begin{array}{c}\text { Machining } \\
\text { performance }\end{array}$ & \multicolumn{1}{c|}{ Remarks } \\
\hline 1 & $\begin{array}{l}\text { V.S. } \\
\text { Aigbodian et } \\
\text { al. (2012) }\end{array}$ & $\begin{array}{l}\text { applied load, } \\
\text { sliding speed } \\
\text { and sliding } \\
\text { distance }\end{array}$ & $\begin{array}{l}\text { Studied using } \\
\text { pin on disc } \\
\text { wear rig }\end{array}$ & wear rate & $\begin{array}{l}\text { The study reported that the reinforcement } \\
\text { of bagasse ash content help in increasing } \\
\text { the wear resistance while ANOVA results } \\
\text { showed that applied load and sliding speed } \\
\text { are the most significant parameters } \\
\text { affecting the wear rate. }\end{array}$ \\
\hline 2 & $\begin{array}{l}\text { Anupam } \\
\text { Agrawal et } \\
\text { al. (2015) }\end{array}$ & $\begin{array}{l}\text { depth of cut, } \\
\text { feed rate and } \\
\text { spindle } \\
\text { speed }\end{array}$ & Turning & $\begin{array}{l}\text { surface } \\
\text { roughness }\end{array}$ & $\begin{array}{l}\text { The study compared multiple regression } \\
\text { analysis, quantile regression analysis and } \\
\text { random forest regression analysis and } \\
\text { observed that random forest regression } \\
\text { model had a better predictability. }\end{array}$ \\
\hline
\end{tabular}


Kumar, S.: Review on Optimization Techniques used for Determining Machining C...

\begin{tabular}{|c|c|c|c|c|c|}
\hline 3 & $\begin{array}{l}\text { Samik } \\
\text { Duttaa et } \\
\text { al.(2015) }\end{array}$ & $\begin{array}{l}\text { depth of cut, } \\
\text { spindle } \\
\text { speed and } \\
\text { feed rate }\end{array}$ & Turning & $\begin{array}{l}\text { tool wear } \\
\text { prediction and } \\
\text { tool condition } \\
\text { monitoring }\end{array}$ & $\begin{array}{l}\text { Combination of Image texture analysis } \\
\text { and support vector regression were } \\
\text { considered to be the best methods for tool } \\
\text { wear prediction }\end{array}$ \\
\hline 4 & $\begin{array}{l}\text { Adel Taha } \\
\text { Abbas et al. } \\
(2016)\end{array}$ & $\begin{array}{l}\text { cutting } \\
\text { speed, feed } \\
\text { rate and } \\
\text { depth of cut }\end{array}$ & Face milling & $\begin{array}{l}\text { surface } \\
\text { roughness }\end{array}$ & $\begin{array}{l}\text { Optimum machining conditions were } \\
\text { obtained by minimizing surface roughness } \\
\text { and maximizing material removal rate. } \\
\text { Feed rate had the most significant effect } \\
\text { while the interaction between feed rate and } \\
\text { depth of cut had a secondary effect on } \\
\text { surface roughness. }\end{array}$ \\
\hline 5 & $\begin{array}{l}\text { Nabeel H. } \\
\text { Alharthi et } \\
\text { al. (2017) }\end{array}$ & $\begin{array}{l}\text { depth of cut, } \\
\text { spindle } \\
\text { speed and } \\
\text { feed rate }\end{array}$ & Face milling & $\begin{array}{l}\text { surface } \\
\text { roughness }\end{array}$ & $\begin{array}{l}\text { Multivariable optimization was employed } \\
\text { to obtain optimal response. It was } \\
\text { detected that higher feed rate led to higher } \\
\text { surface roughness. It was observed from } \\
\text { the comparison result that ANN had } \\
\text { better predictability than regression } \\
\text { analysis }\end{array}$ \\
\hline 6 & $\begin{array}{l}\text { S. } \\
\text { Thirumalai } \\
\text { Kumaran et } \\
\text { al. (2017) }\end{array}$ & $\begin{array}{l}\text { jet speed, } \\
\text { standoff } \\
\text { distance and } \\
\text { transverse } \\
\text { speed }\end{array}$ & $\begin{array}{l}\text { abrasive water } \\
\text { jet machining }\end{array}$ & $\begin{array}{l}\text { surface } \\
\text { roughness }\end{array}$ & $\begin{array}{l}\text { It was observed that on unidirectional } \\
\text { Carbon fiber-reinforced plastic (CFRP) } \\
\text { with fabric woven surface had better } \\
\text { surface finish than on unidirectional } \\
\text { Carbon fiber-reinforced plastic (CFRP) }\end{array}$ \\
\hline
\end{tabular}

Tab. 3. Application of Regression Analysis

\section{Fuzzy logic}

Fuzzy logic was introduced by Dr. Lotfi Zadeh of University of California in 1965. It deals in estimating the degree of truth. In simple words it helps in understanding where a specific condition stands from being completely true or completely false. Every value is divided into grade of 0 or 1 depending upon them being higher or lower than the threshold. These grades are used to represent the fuzzy set. Membership functions are used to indicate the grade of input parameters. Based on the study of M. Chandrasekaran et al. (2010) on various soft computing techniques for optimization it can be proclaimed that the elements in the fuzzy set can have a partial membership in the set. Fuzzy logic helps in estimating if a particular subset belongs to another subset thus changing the undulating problem into linguistic domain of fuzzy logic to obtain an accurate region.

In the literature the prediction using fuzzy set first converts the input data into linguistic terms used in fuzzy logic, this process is known as fuzzification process. Various IF-THEN rules are applied on the translated data to obtain optimum response. The results obtained are again converted into numerical data through a process known as a fuzzification process.

The following review describes the application of fuzzy logic in obtaining the best machining parameters for optimum metal cutting conditions.

M. A. El. Baradie (1997) developed fuzzy logic model to obtain a precise machining condition depending on various input machining parameters. The machining parameters selected were speed, depth of cut, feed rate, workpiece material 
and tool material. Data required for development for fuzzy logic was obtained from various manufacturers, machining data handbook and Metcut research associates. The study reported that the developed fuzzy logic model accurately predicted the output as mentioned in the handbook, it also provides a vital relationship between the hardness of workpiece material and cutting speed. M. A. El. Baradie concluded that the availability of the machining data for development of algorithms for soft computing techniques will aid in exploring and expanding the automated manufacturing system.

Ruey-Jing Lian et al. (2005) applied the grey theory algorithm to fuzzy control system to maintain a constant cutting force in turning operation on traditional lathe machine which was installed with load cell to measure the cutting force, servo motors to control feed rod action and induction motor to control the spindle speed. Mathematical model was developed by keeping the feed rate constant to determine the cutting force. A fuzzy logic model was developed with and without applying the grey theory algorithm. The grey theory helps in estimating the system variation by predicting the output error of the next stage. Experiments were conducted on medium carbon steel (S45C) using wolfram carbide tool, these experiments divided in two parts where data was collected keeping the depth of cut constant in first part and in second part data was collected by varying the depth of cut and the data was used to predict the changes in the parameters like feed rate that should be made to obtain constant cutting force using grey fuzzy prediction control model and traditional fuzzy control model. The study reported that based on the experimental data obtained, the grey prediction fuzzy controller performed better in controlling the cutting force that the traditional fuzzy controller. Figure 5 shows the working of the fuzzy controller used in the study where the inputs undergoes three important stages.

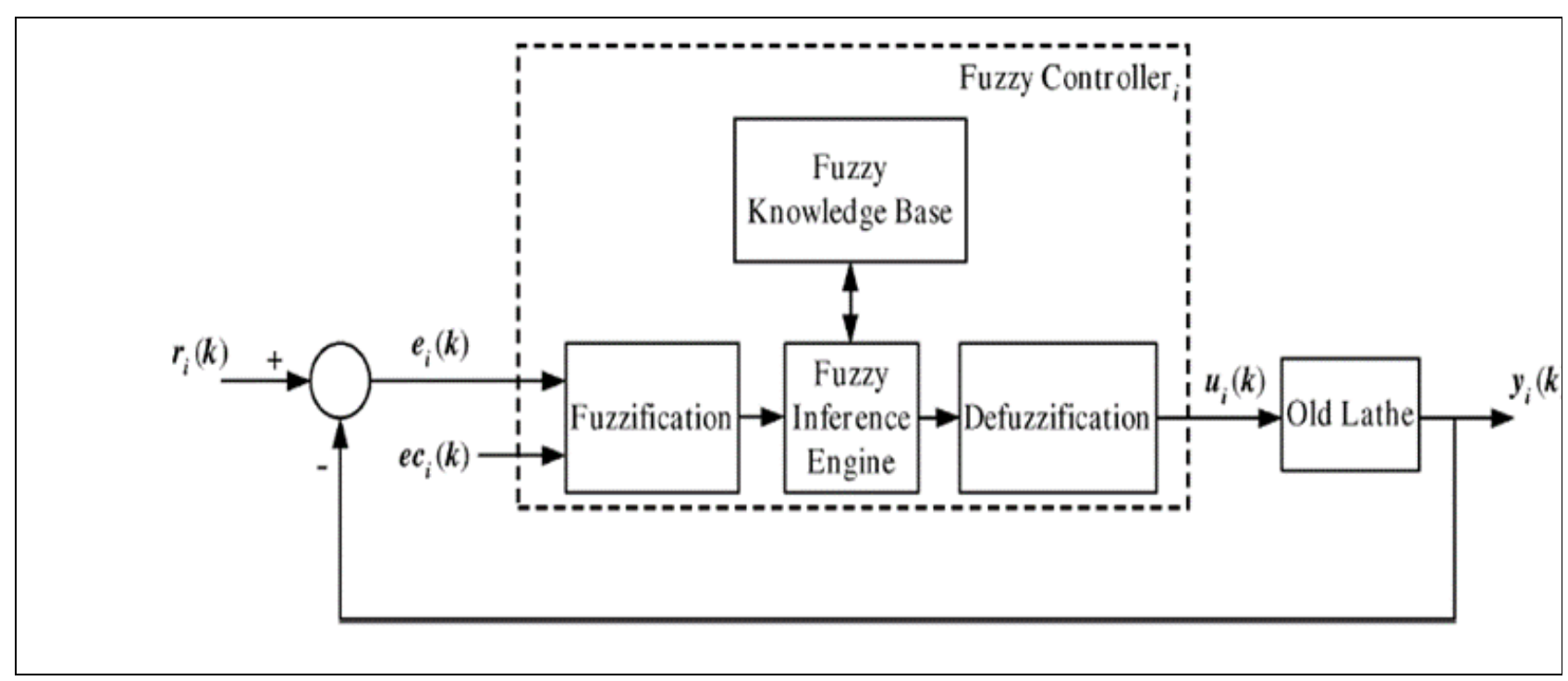

Fig. 5. Block diagram of fuzzy controller used in the research work

Asif Iqbal et al. (2007) used fuzzy logic model to predict tool life, surface roughness and cutting force in hard milling of AISI D2 with a K30 carbide flat end milling cutter coated with single layer of TiAlN. A full factorial design was implemented to collect data by varying parameters like milling orientation, tool helix angle, coolant, workpiece material hardness and tool helix angle. The research focuses 
on optimization of the parameters to obtain maximum tool life and minimum surface roughness. Analysis of variance (ANOVA) was employed to recognize the dominant parameters affecting the response. The results of ANOVA suggested that milling orientation and material hardness were the dominant parameters affecting tool life while milling orientation had the most significant effect on cutting force and surface roughness. The study reported that the developed fuzzy model can enlist all the values of the machining parameters considered once the objective is specified along with the material hardness and lubrication condition. The authors concluded that a similar expert system can be developed to optimize parameters like tool tilt angle, cutting speed, feed rate and depth of cut.

Mohsen Marani Barzani et al. (2014) developed fuzzy logic to study the effect of machining parameters like feed rate, cutting speed and additives like bismuth, antimony and strontium on surface roughness of Die Casting Alloy of Al-Si-Cu-Fe for turning operation. Experiments were conducted by varying the machining parameters in various combinations to check the accuracy of the developed fuzzy logic. The values obtained through experiments were found to be very close to that of the predicted values by fuzzy logic model showing the high accuracy of fuzzy logic. Pareto ANOVA results stated that feed rate greatly affected the surface roughness followed by cutting speed. It was found that best surface roughness is found low feed rate and high cutting speed. The study concluded that the workpiece containing Bismuth that high surface finish as compared to other additives.

Besmir Cuka and Dong Won Kin (2016) monitored the tool condition for end milling of AISI 1045 steel with a TiAlN coated high speed steel tool by developing fuzzy model by data acquired from using different types of sensors. The various sensors were used to measure spindle vibration, cutting force, machining sound and spindle current signal. The signals were analyzed and filtered to develop an inference system which would provide the information of the tool condition, helping the operator to make decision regarding change in cutting conditions or tool change. The study emphasized that the tool life can be increased by controlling the cutting speed and by avoiding interruption in the machining process. It was also reported that the results obtained from dynamometer and current sensor were highly correlated indicating that the either of the results can be used for validation of the other. The study also suggested that a tool condition monitoring system can be developed for complex machining paths with complex tool geometry and varying sizes using fuzzy inference system.

\subsection{Application of fuzzy logic in various machining process}

Based on the literature referred, Table 4 enlists the application of fuzzy logic model to predict the response in manufacturing processes using various algorithms.

\begin{tabular}{|l|l|l|l|l|l|}
\hline No & Author & \multicolumn{1}{|c|}{ Parameters } & Process & $\begin{array}{l}\text { Machining } \\
\text { performance }\end{array}$ & \multicolumn{1}{|c|}{ Remarks } \\
\hline 1 & $\begin{array}{l}\text { M. A. A. } \\
\text { El. } \\
\text { Baradie } \\
(1997)\end{array}$ & $\begin{array}{l}\text { speed, depth of cut, } \\
\text { feed rate, workpiece } \\
\text { material and tool } \\
\text { material }\end{array}$ & Milling & $\begin{array}{l}\text { To predict } \\
\text { machining } \\
\text { condition }\end{array}$ & $\begin{array}{l}\text { The developed model accurately predicted the } \\
\text { machining condition as mentioned in the } \\
\text { handbook which was used to take reference } \\
\text { input values. }\end{array}$ \\
\hline
\end{tabular}




\begin{tabular}{|c|c|c|c|c|c|}
\hline 2 & $\begin{array}{l}\text { Ruey- } \\
\text { Jing } \\
\text { Lian et } \\
\text { al. } \\
(2005) \\
\end{array}$ & $\begin{array}{l}\text { Feed rate, cutting speed } \\
\text { and depth of cut }\end{array}$ & Turning & Cutting force & $\begin{array}{l}\text { Two Fuzzy logic models was developed, one } \\
\text { using grey theory algorithm and other without } \\
\text { applying the algorithm. It was observed that } \\
\text { the model with grey theory algorithm } \\
\text { performed better than the other model. }\end{array}$ \\
\hline 3 & $\begin{array}{l}\text { Asif } \\
\text { Iqbal et } \\
\text { al. } \\
(2007)\end{array}$ & $\begin{array}{l}\text { milling orientation, } \\
\text { tool helix angle, } \\
\text { coolant, workpiece } \\
\text { material hardness and } \\
\text { tool helix angle }\end{array}$ & $\begin{array}{l}\text { Hard } \\
\text { milling }\end{array}$ & $\begin{array}{l}\text { tool life, } \\
\text { surface } \\
\text { roughness } \\
\text { and cutting } \\
\text { force }\end{array}$ & $\begin{array}{l}\text { The developed model was capable to predict } \\
\text { the responses precisely. }\end{array}$ \\
\hline 4 & $\begin{array}{l}\text { Mohsen } \\
\text { Marani } \\
\text { Barzani } \\
\text { et al. } \\
(2014)\end{array}$ & feed rate, cutting speed & Turning & $\begin{array}{l}\text { surface } \\
\text { roughness }\end{array}$ & $\begin{array}{l}\text { It was observed from the experimental results } \\
\text { that the fuzzy inference system predicted the } \\
\text { response accurately. ANOVA results depicted } \\
\text { that feed rate greatly affected the surface } \\
\text { roughness followed by cutting speed }\end{array}$ \\
\hline 5 & $\begin{array}{l}\text { Besmir } \\
\text { Cuka } \\
\text { and } \\
\text { Dong } \\
\text { Won } \\
\text { Kin } \\
(2016)\end{array}$ & $\begin{array}{lr}\text { spindle } & \text { vibration, } \\
\text { cutting } & \text { force, } \\
\text { machining } & \text { sound and } \\
\text { spindle current signal }\end{array}$ & $\begin{array}{l}\text { End } \\
\text { Milling }\end{array}$ & $\begin{array}{l}\text { tool condition } \\
\text { monitoring }\end{array}$ & $\begin{array}{l}\text { The fuzzy inference system was successful in } \\
\text { providing accurate tool condition and this } \\
\text { system can be employed for monitoring } \\
\text { complex tool geometry and machining path. }\end{array}$ \\
\hline
\end{tabular}

Tab. 4. Application of Fuzzy Logic

\section{Artificial neural network}

Artificial neural network (ANN) is one of the most widely used soft computing techniques in the field of optimization. The concept of ANN emerges from the working of the neural networks or nerves of the brain of a living being who can identify any object living or non-living once it has trained its mind through various medium like images or sensations. The nerve cells keep on updating the stored information through the various experiences that the living being undergoes. Similarly, ANN is trained by the experimental data. The use of this data is divided into two parts, major portion is used for training the neural network while the remaining data is used for validation purpose and this can be compared to the behavior of the living being. When a living being undergoes a similar experience which had happened earlier, the reaction or the feelings associated with the incident are stored in the neural network, it can be said that the neural network is now trained by that particular experience. When the same situation arises, the network is triggered even by the slightest possible sign and the living being reacts in the exact same manner which validates the information stored.

ANN consists of one input layer, one or more hidden layers and one output layer. There are two types of pattern for neural networks, one with single input and multiple output while the other with multiple input and single output. Depending upon the input parameters considered and the output required the pattern is selected.

A feed forward neural network with only one hidden layer is known as radial basis function (RBF) while the one with one or more hidden layer is known as multilayer 
Kumar, S.: Review on Optimization Techniques used for Determining Machining C...

perceptron. In feed forward neural network the information is constantly passed on the next layer in only one direction that is from the input layer it passes to hidden layer and from hidden layer it moves onto the output layer, the information in no condition moves around in a cycle whereas in back propagated neural network the processed output is sent back as a feedback to calculate the error or the loss function. Since the information is sent backwards hence the name back propagated neural network. It is evident through various research work that the results obtained by ANN are accurate and its performance against optimization techniques like regression analysis and response surface methodology has been fairly high.

The following review considers the application of ANN in optimization of machining parameters to obtain optimal machining conditions.

K. Venkata Rao et al. (2014) showed that neural networks can be used in selection of proper cutting parameters to reduce tool wear, tool vibration and surface roughness. Taguchi L8 orthogonal array was used to analyze the experimental data obtained by varying nose radius, cutting speed, and feed rate on AISI 316 stainless steel with cemented carbide tools for boring operation. A four layered neural network was developed with back propagation algorithm to predict surface roughness, vibration of work piece and tool wear. The study reported that the estimated values by ANN were very close to experimental data indicating high predicting ability. It also suggested change of tool at right time to obtain high quality products.

Doriana M. D'Addona et al. (2015) applied of soft computing techniques to predict tool wear of AISI 1045 with tungsten carbide tool for turning operation. Artificial Neural Network and DNA based computing were applied to study the effects of feed rate, cutting speed, machining time and depth of cut on tool wear. Images of the tool wear were taken to train the back propagation neural network at different cutting combinations to recognize different pattern of tool wear, DNA based computing was applied to identify even the minute difference in the wear pattern from the images. The study concluded that ANN successfully predicts the degree of tool wear while DNA based computing can be trusted for recognize the difference in image patterns.

A. Khorasani et al. (2015) developed an artificial neural network model to predict surface roughness for full slot milling process of Al and St using high speed steel end mill cutter. The parameters selected as input were speed, depth of cut, feed rate, lubrication condition, material type, white noise (disturbances) and machine vibration. A full factorial design of experiment was implemented to acquire experimental data. The white noises were simulated in the neural network to create more realistic conditions in milling operation. It was reported that the output from the ANN model and the surface roughness obtained from the experiments were highly related showing high accuracy of the ANN model and the neural network with architecture of $7 * 6 * 5 * 3 * 1$ comparatively predicted accurate results. The study concluded that the designed model would be very useful in setting parameters and checking the cutting conditions in manufacturing process. 
Biswajit Das et al. (2015) investigated the machining ability of $\mathrm{Al}-4.5 \% \mathrm{Cu}-\mathrm{TiC}$ metal matrix composite by developing an artificial neural network (ANN) model to predict surface roughness and cutting force by varying input parameters like feed rate, depth of cut and cutting speed. The results were compared with Al-4.5Cu alloy and Al$4.5 \% \mathrm{Cu}-\mathrm{SiC}$. The chips formed during the end milling process of all three work pieces using solid carbide cutter were also studied. The surface roughness was measured using $3 \mathrm{D}$ profilometer while the cutting forces were measured using dynamometer. The experiment was designed using Taguchi's L25 orthogonal array. The data collected was used to train and test the neural network model developed using feed forward back propagation algorithm. The study reported that the data predicted by ANN model was highly accurate when compared with the experimental results also the comparison results of all three workpiece suggested that the increase the quantity of Tic and Sic increases the cutting force while $\mathrm{Al}-4.5 \mathrm{Cu}$ produced maximum cutting force. Al$4.5 \% \mathrm{Cu}-\mathrm{TiC}$ had better surface finish compared to other work pieces while the chip formation of $\mathrm{Al}-4.5 \% \mathrm{Cu}$ was discontinuous compared to regular thick chip formation in other two work pieces. The study concluded that the developed ANN model predicted the cutting force and surface roughness with minimum error. The microstructure of $\mathrm{Al}-4.5 \mathrm{Cu}$ alloy, $\mathrm{Al}-4.5 \% \mathrm{Cu}-\mathrm{TiC}$ and $\mathrm{Al}-4.5 \% \mathrm{Cu}-\mathrm{SiC}$ and the chips formed during machining process are shown in figure 6 and 7 respectively.
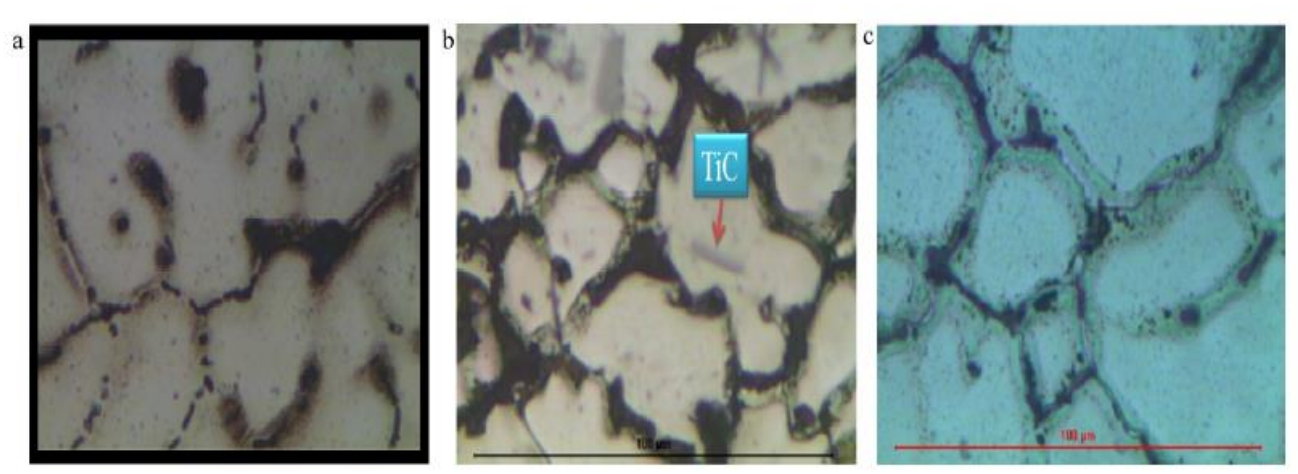

Fig. 6. Microstructures of $\mathrm{Al}-4.5 \mathrm{Cu}$ alloy, $\mathrm{Al}-4.5 \% \mathrm{Cu}-\mathrm{TiC}$ and $\mathrm{Al}-4.5 \% \mathrm{Cu}-\mathrm{SiC}$ respectively

Cyril Drouillet et al. (2016) attempted to find the remaining useful tool life using artificial neural network (ANN). The workpiece material used for the milling process using carbide inserts was stainless steel SS403. The tool condition was monitored when the spindle speeds were varied keeping the feed rate and depth of cut constant. The spindle speeds used were $1380,1800,2700$ and $4100 \mathrm{rpm}$ and the data acquisition module was used to monitor spindle speed while the period up to which the flank wear to reaches $0.3 \mathrm{~mm}$ was considered as the tool life. The neural network was developed using three different training functions namely, traincgb, trainlm and trainbfg. The study reported that the root mean square value of power highly affected the tool wear and this neural network model can be used for any spindle speed as the uncertainties are also included while developing this model. It was also concluded that predictions from trainlm training model were accurate compared to other two. Figure 8 shows the process used to monitor the process parameters using sensors and signals. 
Kumar, S.: Review on Optimization Techniques used for Determining Machining C...

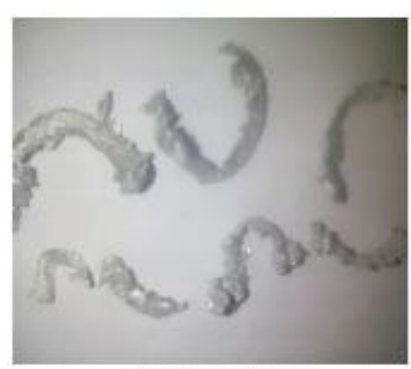

Al-4.5Cu alloy

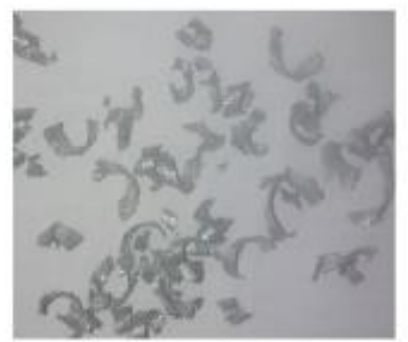

Al-4.5Cu-10TiC

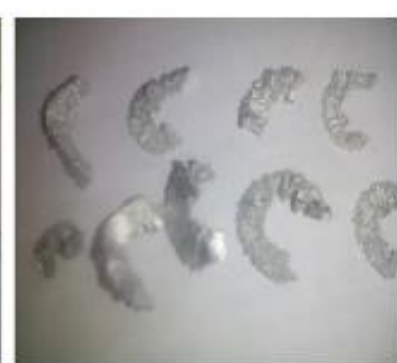

Al-4.5Cu-5TiC

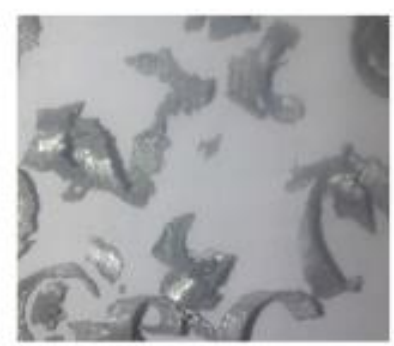

Al- $4.5 \mathrm{Cu}-3 \mathrm{SiC}$

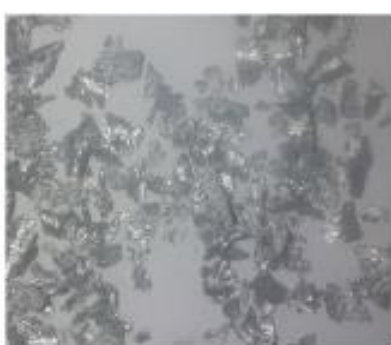

$\mathrm{Al}-4.5 \mathrm{Cu}-7 \mathrm{SiC}$

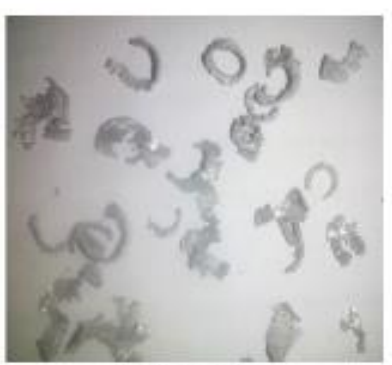

Al-4.5Cu-7TiC

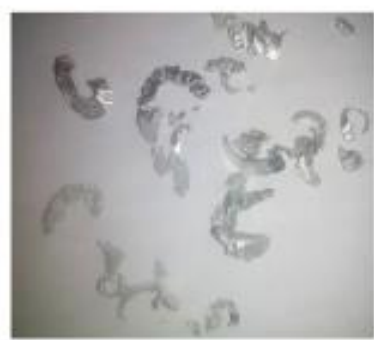

Al- $4.5 \mathrm{Cu}-5 \mathrm{SiC}$

Fig. 7. Chips formed during machining process of $\mathrm{Al}-4.5 \mathrm{Cu}$ alloy, $\mathrm{Al}-4.5 \% \mathrm{Cu}-\mathrm{TiC}$ and $\mathrm{Al}-4.5 \% \mathrm{Cu}-\mathrm{SiC}$ respectively

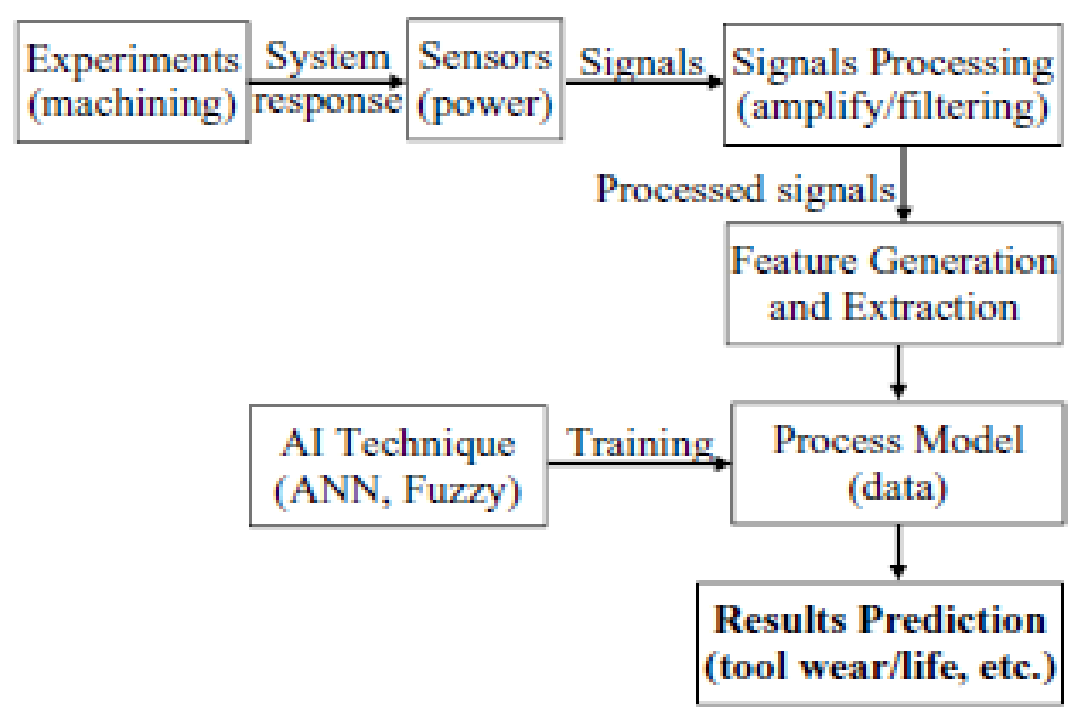

Fig. 8. Procedure for intelligent monitor system

\subsection{Application of ANN in Manufacturing Processes}

Based on the referred literature, Table 5 gives an overview of application of ANN models in predicting responses in various machining processes. 


\begin{tabular}{|c|c|c|c|c|c|}
\hline No & Author & Parameters & Process & $\begin{array}{c}\text { Machining } \\
\text { performance }\end{array}$ & Remark \\
\hline 1 & $\begin{array}{l}\text { K. } \\
\text { Venkata } \\
\text { Rao et al. } \\
(2014)\end{array}$ & $\begin{array}{l}\text { nose radius, cutting } \\
\text { speed, and feed rate }\end{array}$ & Boring & $\begin{array}{l}\text { tool wear, tool vibration } \\
\text { and surface roughness }\end{array}$ & $\begin{array}{l}\text { The developed ANN model used } \\
\text { back propagation algorithm to } \\
\text { predict the responses. The study } \\
\text { reported the developed ANN } \\
\text { model had a very high } \\
\text { predictability }\end{array}$ \\
\hline 2 & $\begin{array}{l}\text { Doriana } \\
\text { M. } \\
\text { D’Addona } \\
\text { et al. } \\
(2015)\end{array}$ & $\begin{array}{l}\text { feed rate, cutting } \\
\text { speed, machining } \\
\text { time and depth of } \\
\text { cut }\end{array}$ & Turning & tool wear & $\begin{array}{l}\text { ANN model developed was } \\
\text { highly accurate in predicting the } \\
\text { tool wear while use of DNA } \\
\text { based computing helped in } \\
\text { finding a slight difference in the } \\
\text { wear images which help in } \\
\text { increasing the prediction ability. }\end{array}$ \\
\hline 3 & $\begin{array}{l}\text { A. } \\
\text { Khorasani } \\
\text { et al. } \\
(2015)\end{array}$ & $\begin{array}{l}\text { speed, depth of cut, } \\
\text { feed rate, } \\
\text { lubrication } \\
\text { condition, material } \\
\text { type, white noise } \\
\text { (disturbances) and } \\
\text { machine vibration }\end{array}$ & $\begin{array}{l}\text { Slot } \\
\text { milling }\end{array}$ & surface roughness & $\begin{array}{l}\text { The developed model was highly } \\
\text { accurate. Use of white noise in } \\
\text { the developed ANN model } \\
\text { increases the prediction } \\
\text { capability. }\end{array}$ \\
\hline 4 & $\begin{array}{l}\text { Biswajit } \\
\text { Das et al. } \\
(2015)\end{array}$ & $\begin{array}{l}\text { Feed rate, depth of } \\
\text { cut and cutting } \\
\text { speed. }\end{array}$ & Milling & $\begin{array}{l}\text { surface roughness and } \\
\text { cutting force }\end{array}$ & $\begin{array}{l}\text { The ANN model predicted the } \\
\text { response value with minimum } \\
\text { error. }\end{array}$ \\
\hline 5 & $\begin{array}{l}\text { Cyril } \\
\text { Drouillet } \\
\text { et al. } \\
(2016)\end{array}$ & $\begin{array}{l}\text { spindle speeds, feed } \\
\text { rate and depth of } \\
\text { cut constant }\end{array}$ & Milling & tool life & $\begin{array}{l}\text { The neural networks was } \\
\text { developed using three training } \\
\text { functions traincgb, trainlm and } \\
\text { trainbfg, out of which trainlm } \\
\text { training model was accurate } \\
\text { compared to other two. }\end{array}$ \\
\hline
\end{tabular}

Tab. 5. Application of ANN

\subsection{Adaptive Neuro Fuzzy Inference System}

Adaptive Neuro Fuzzy Inference system (ANFIS) is a combination of both fuzzy logic and neural networks. ANFIS gains benefits from both the methods to achieve optimum results. A fuzzy logic system or fuzzy set is developed by assigning grades and developing membership function. The neuro adaptive technique helps in analyzing and understanding the data. The input data is exposed to the IF-THEN rules to obtain the results. It basically provides the fuzzy inference system to achieve the required output while the neural technique helps in learning from the data.

A. I. Azmi et al. (2013) developed a multiple regression analysis and adaptive neuro fuzzy inference model (ANFIS) to predict tool wear on carbide insert while end milling process on glass fiber reinforced polymer composite. The varying parameters selected were fiber orientation angle, linear cutting speed, feed rate and spindle speed as depth of cut was kept constant. The experimental data was collected and the tool wear was recorded using optical microscope and from the images taken from the digital camera attached to the microscope. Multiple regression model was built using the experimental data collected to predict tool wear. ANFIS five layer structure was developed for multiple input and single output. Some part of data collected from 
Kumar, S.: Review on Optimization Techniques used for Determining Machining C...

experiment was used to train the model while other part is used for testing. It was observed that machining across (90 degree) the direction of fiber increases tool wear compared to machining along (0 degree) the fiber orientation. Comparing with the experimental results it was observed that both multiple regression and ANFIS model were highly accurate. The study concluded that even though the regression model was accurate in predicting tool wear, the use of ANFIS in tool wear prediction helps in obtaining improved results. Figure 9 shows the tool wear observed during the end milling process
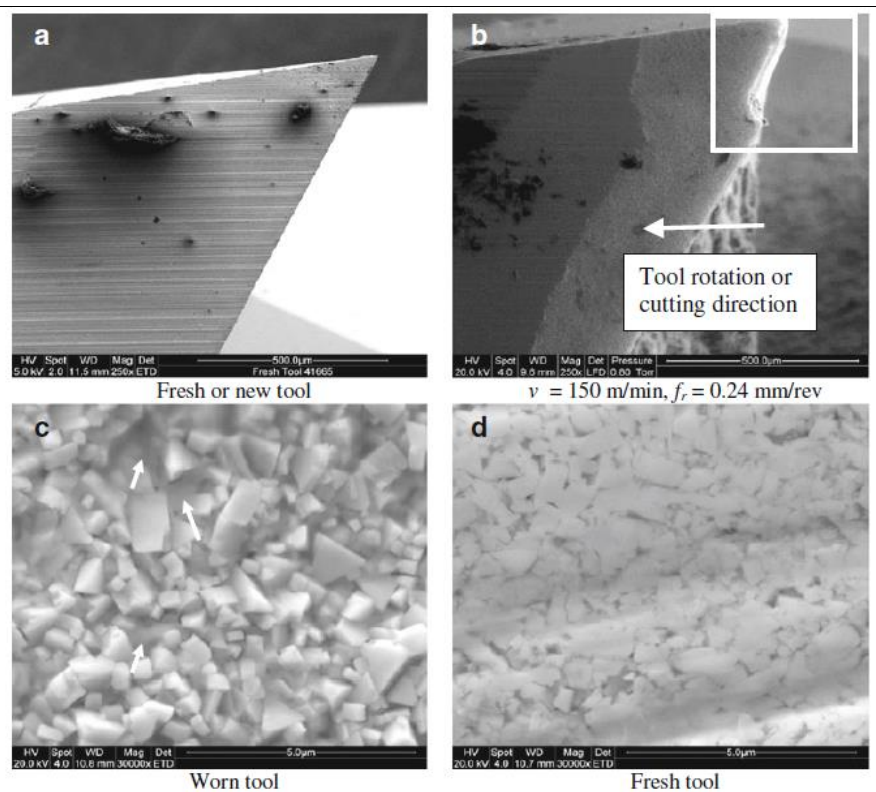

Fig. 9. Tool wear observed during end milling process

Muhammad Rizalet al. (2013) integrated ANFIS and I-kaz method to develop a model that would predict tool wear using the signals from cutting force. Strain gauges were used to measure changes in feed direction and tangential direction during the turning operation on bar of JIS S45C carbon steel using carbide coated insert. ANFIS structure of multiple input and single output was developed considering input parameters as coefficients of I-kaz for feed force and cutting force, speed, depth of cut and feed rate and flank wear as output. The kurtosis algorithm for I-kaz method was used to analyze and interpret the signals by decomposing the frequency signals. The study reported that the results obtained from experimental results and the developed model was highly accurate. The accuracy level achieved was in between $95.93 \%$ to $97.70 \%$. It was concluded that the developed system has high correlation with the data acquired by experiments and can be used in any manufacturing unit.

Vineet Jain and Tilak Raj (2016) attempted to develop an adaptive neuro fuzzy inference model (ANFIS) to monitor tool life of an unmanned manufacturing unit based on surface roughness. The authors state that the cutting force is an important parameter affecting the surface roughness and tool wear, hence an ANFIS model was built analyze the cutting force signals to estimate the tool condition. A piezoelectric dynamometer was used to measure cutting force. A multiple input and single output ANFIS structure was developed considering input parameters as depth of cut, speed, 
feed rate and cutting force while the output obtained was surface roughness. Experiments were conducted on lathe machine for turning process and the data acquired was used to train and test the ANFIS model. The study reported that the predicting capability of ANFIS model is high and coefficient of correlation around $95.28 \%$. The study concluded that the developed model successfully monitored the tool life of an unmanned production unit and predicted the output accurately.

Adel T. Abbas et al. (2017) investigated the effect of cutting parameters like feed rate, depth of cut and cutting speed on surface roughness of the high strength steel of grade $\mathrm{H}$ also known as gun steel with an uncoated tungsten carbide insert for turning operation. The predicting capability of ANFIS and regression analysis were compared to understand their performance characteristics. Full factorial design was premediated to investigate the effects of the cutting parameters on surface roughness. Multilinear regression model was developed using the experimental data to establish a relationship between the responses and machining parameters. ANFIS model was built using fuzzy logic and neural network so that the model can continuously adapt to fuzzy inference system. The data obtained through experiment was used for training and validation of ANFIS model. The study reported that the ANFIS model has a marginally better predicting capability than regression model. Optimum machining conditions were obtained using desirability function approach and it was reported that the optimum material removal rate was observed when surface finish was maintained below $0.8 \mu \mathrm{m}$. The column chart in figure 10 shows the predicted and actual values of surface roughness.

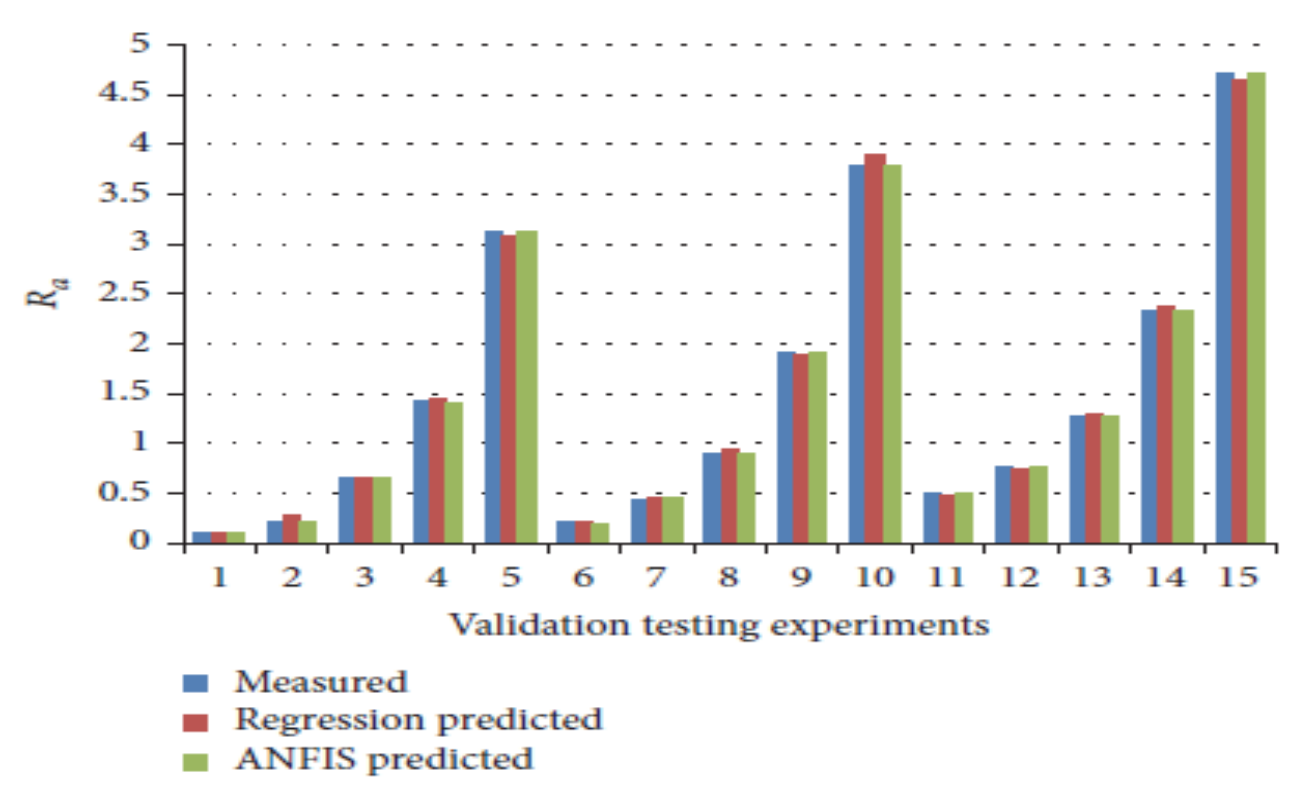

Fig. 10. Column chart indicating measured and the predicted values

Binayak Sen et al. (2017) developed an ANFIS structure to predict the performance of machining parameters on Inconel 690 workpiece for milling process with cubic boron nitride coated tool.

The machining parameters selected were, feed rate, cutting speed, width and depth of cut and while the responses estimated were surface roughness, cutting force 
and cutting temperature. Design of experiment was employed to plan the experiment while regression analysis was used to predict the response using controlling factors. Results from analysis of variance for $95 \%$ confidence interval indicated that depth of cut and speed are the most influencing parameters. Some part of the experimental data obtained was used to train the ANFIS model while the other part was used for prediction. The results from ANFIS were compared to actual values obtained and it was observed that the predictions were highly accurate. Also artificial neural network model (ANN) was built using data collected from the experiments and the performance of ANN and ANFIS were compared. It was reported that ANFIS model performed better than the ANN model. The study concluded that predictions from ANFIS models can highly trusted.

\subsection{Application of ANFIS in Manufacturing Processes}

Table 6 lists the application of ANFIS in predicting response by developing models to predict the response precisely in various manufacturing process.

\begin{tabular}{|c|c|c|c|c|c|}
\hline No & Author & Parameters & Process & $\begin{array}{l}\text { Machining } \\
\text { Performance }\end{array}$ & Remark \\
\hline 1 & $\begin{array}{l}\text { A. I. Azmi } \\
\text { et al. }(2013)\end{array}$ & $\begin{array}{l}\text { were fiber } \\
\text { orientation } \\
\text { angle, linear } \\
\text { cutting speed, } \\
\text { feed rate } \\
\text { spindle speed } \\
\text { and depth of } \\
\text { cut }\end{array}$ & $\begin{array}{l}\text { End } \\
\text { Milling }\end{array}$ & tool wear & $\begin{array}{l}\text { The developed } 5 \text { layer ANFIS model could predict } \\
\text { the output accurately. It was observed that It was } \\
\text { observed that machining across ( } 90 \text { degree) the } \\
\text { direction of fiber increases tool wear compared to } \\
\text { machining along ( } 0 \text { degree) the fiber orientation }\end{array}$ \\
\hline 2 & $\begin{array}{l}\text { Muhammad } \\
\text { Rizal et al. } \\
(2013)\end{array}$ & $\begin{array}{l}\text { Depth of cut, } \\
\text { cutting speed } \\
\text { and feed rate }\end{array}$ & Turning & Tool wear & $\begin{array}{l}\text { It was observed that the predicted data from the } \\
\text { ANFIS model was highly correlated to the } \\
\text { experimental data showing high level of accuracy }\end{array}$ \\
\hline 3 & $\begin{array}{l}\text { Vineet Jain } \\
\text { and Tilak } \\
\text { Raj (2016) }\end{array}$ & $\begin{array}{l}\text { depth of cut, } \\
\text { speed, feed } \\
\text { rate and } \\
\text { cutting force }\end{array}$ & Turning & $\begin{array}{l}\text { Tool life } \\
\text { monitoring } \\
\text { based on } \\
\text { surface } \\
\text { roughness }\end{array}$ & $\begin{array}{l}\text { The multi input single output ANFIS model was } \\
\text { successful in predicting the tool life and had a } \\
\text { correlation of } 95.28 \% \text { with the experimental data. }\end{array}$ \\
\hline 4 & $\begin{array}{l}\text { Adel T. } \\
\text { Abbas et al. } \\
(2017)\end{array}$ & $\begin{array}{l}\text { feed rate, } \\
\text { depth of cut } \\
\text { and cutting } \\
\text { speed }\end{array}$ & Turning & $\begin{array}{l}\text { surface } \\
\text { roughness }\end{array}$ & $\begin{array}{l}\text { ANN and ANFIS models were developed to predict } \\
\text { the output and it was observed that ANFIS model } \\
\text { had slightly better predictability than ANN model. }\end{array}$ \\
\hline 5 & $\begin{array}{l}\text { Binayak } \\
\text { Sen et al. } \\
(2017)\end{array}$ & $\begin{array}{l}\text { feed rate, } \\
\text { cutting speed, } \\
\text { width and } \\
\text { depth of cut }\end{array}$ & Milling & $\begin{array}{l}\text { surface } \\
\text { roughness, } \\
\text { cutting force } \\
\text { and } \\
\text { temperature }\end{array}$ & $\begin{array}{l}\text { Based on the experimental data it was observed that } \\
\text { ANFIS model accurately predicted the surface } \\
\text { roughness values and performed better than the } \\
\text { ANN model. }\end{array}$ \\
\hline
\end{tabular}

Tab. 6. Application of ANFIS 


\subsection{Overview of various optimization techniques used in machining process}

The column chart in figure 11 represents the various optimization techniques used in manufacturing processes based on the literature referred. It can be observed that Taguchi method is used maximum times to find optimum machining conditions in turning operations followed by ANN in milling operation.

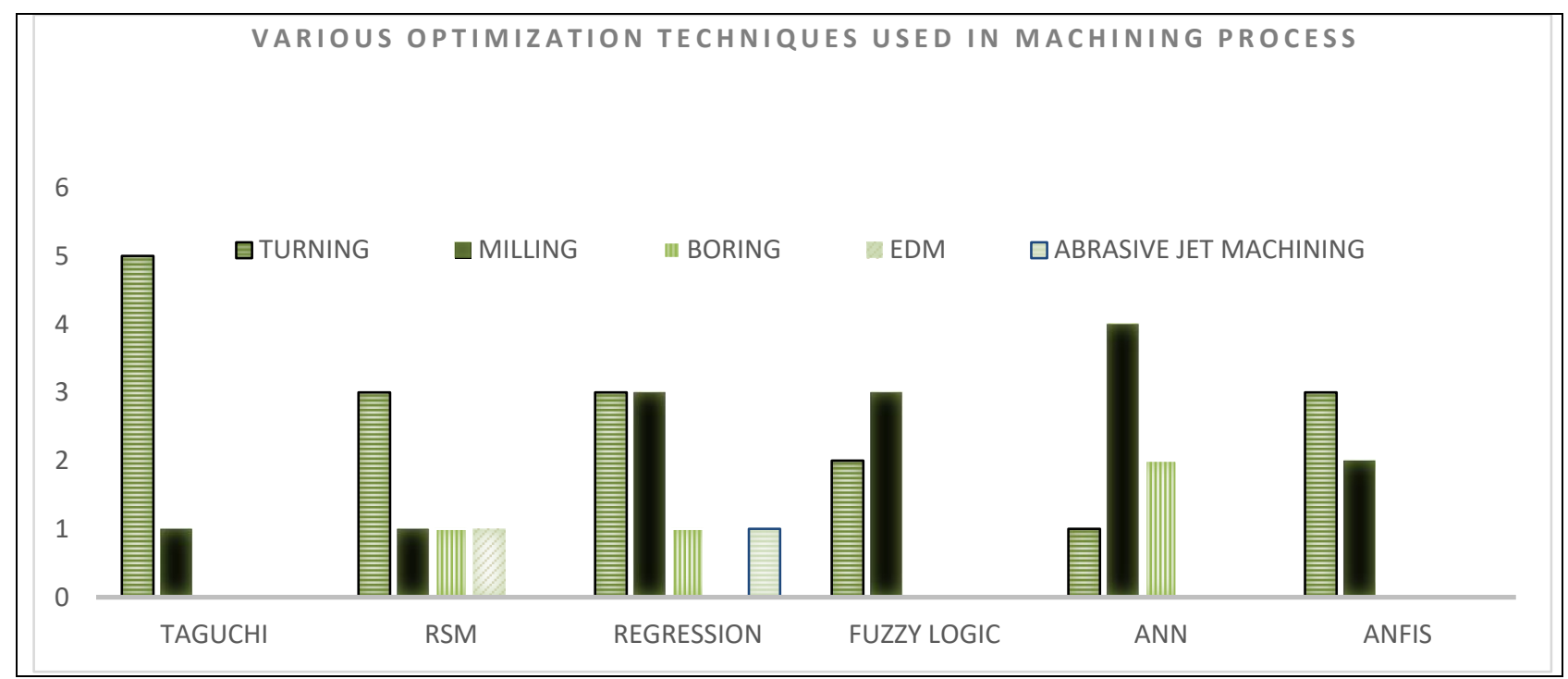

Fig. 11. Column Chart depicting Application of Various Optimization Techniques in Machining Processes

\section{Conclusion}

The literature review gives a brief insight of application of various statistical and soft computing techniques for optimization of machining parameters to achieve required results. It is observed that every method has a capability to predict the response close to the measured value, however the level of accuracy differs from method to method.

Soft computing techniques like fuzzy logic, artificial neural network or adaptive neuro inference system have a higher predicting ability than the Taguchi method, response surface methodology and regression analysis. The comparison results between the soft computing techniques depict that ANFIS has the highest level of accuracy in predicting the response as it integrates both neural network and fuzzy inference system in estimating the response.

Taguchi method has been successful in predicting the responses accurately using signal to noise while the results from comparison of response surface methodology (RSM) and regression analysis indicate that regression models perform better than the RSM model. Analysis of variance (ANOVA) plays a very critical part in obtaining optimum machining conditions by calculating the percentage contribution of every machining parameter on the response. Thus, from the literature review it can be stated that optimization techniques have been successful in determining the machining parameters to obtain optimal response. 
Kumar, S.: Review on Optimization Techniques used for Determining Machining C...

\section{References}

S. Kumar, Meenu and P.S. Satsangi, Multiple-response optimization of turning machining by the taguchi method and the utility concept using uni-directional glass fiber-reinforced plastic composite and carbide (k10) cutting tool, Journal of Mechanical Science and Technology 27 (2013) 2829-2837.

D. Philip Selvaraj, P. Chandramohan, M. Mohanraj, Optimization of surface roughness, cutting force and tool wear of nitrogen alloyed duplex stainless steel in a dry turning process using Taguchi method, Measurement 49 (2014) 205-215.

Turgay Kivak, Optimization of surface roughness and flank wear using the Taguchi method in milling of Hadfield steel with PVD and CVD coated inserts, Measurement 50 (2014), 19-28.

M. Gupta, S. Kumar, Investigation of surface roughness and MRR for turning of UDGFRP using PCA and Taguchi method, Engineering Science and Technology 18, an International Journal (2015) 70-81.

N. Mandal, B. Doloi, B. Mondal, Surface Roughness Prediction Model using Zirconia Toughened Alumina (ZTA) Turning Inserts: Taguchi Method and Regression Analysis, J. Inst. Eng. India Ser. C (2015).

O. Zerti, M.A. Yallese, R. Khettabi, Kamel Chaoui,Tarek Mabrouki, Design optimization for minimum technological parameters when dry turning of AISI D3 steel using Taguchi method, Int J Adv Manuf Technol(2016).

Ashvin J. Makadia, J.I. Nanavati, Optimisation of machining parameters for turning operations based on response surface methodology, Measurement 46 (2013) 15211529

S. Gopalakannan ,T. Senthilvelan, Optimization of machining parameters for EDM operations based on central composite design and desirability approach, Journal of Mechanical Science and Technology 28 (3) (2014) 1045-1053.

B. Bhardwaj, R. Kumar, P. K. Singh, An improved surface roughness prediction model using Box-Cox transformation with RSM in end milling of EN 353, Journal of Mechanical Science and Technology 28 (12) (2014) 5149-5157.

M. Kamruzzaman, S. S. Rahman, Md. Z. I. Ashraf, N. R. Dhar, Modeling of chip-tool interface temperature using response surface methodology and artificial neural network in HPC-assisted turning and tool life investigation, Int J Adv Manuf Technol (2016).

K. Venkata Rao, P. B. G. S. N. Murthy, Modeling and optimization of tool vibration and surface roughness in boring of steel using RSM, ANN and SVM, J Intell Manuf (2016).

P. Sahoo, A. Pratap and A. Bandyopadhyay, Modeling and optimization of surface roughness and tool vibration in CNC turning of Aluminum alloy using hybrid RSMWPCA methodology, International Journal of Industrial Engineering Computations 8 (2017) 385-398. 
V. S. Aigbodian, S .B. Hassan, J. O. Agunsoye, Effect of bagasse ash reinforcement on dry sliding wear behavior of polymer matrix composites, Materials and Design 33 (2012) 322-327.

Anupam Agrawal, S. Goel, W. B. Rashid, M. Price, Prediction of surface roughness during hard turning of AISI 4340 steel (69 HRC), Applied Soft Computing 30 (2015) 279-286.

S. Dutt, S. K. Pal, R. Sen, On-machine tool prediction of flank wear from machined surface images using texture analyses and support vector regression, Precision Engineering (2015).

Adel. T. Abbas, A. E. Ragab, E. Ali Al Bahkali, Ehab Adel El Danaf, Optimizing Cutting Conditions for Minimum Surface Roughness in Face Milling of High Strength Steel Using Carbide Inserts, Advances in Materials Science and Engineering Volume 2016 (2016).

Nabeel H. Alharthi, Sedat Bingol, Adel T. Abbas, Adham E. Ragab, Ehab A. El-Danaf, Hamad F. Alharbi, Optimizing Cutting Conditions and Prediction of Surface Roughness in Face Milling of AZ61 Using Regression Analysis and Artificial Neural Network, Advances in Materials Science and Engineering, Volume 2017 (2017).

S. Thirumalai Kumaran, Tae Jo Ko , M. Uthayakumar, Md. Mofizul Islam, Prediction of surface roughness in abrasive water jet machining of CFRP composites using regression analysis, Journal of Alloys and Compounds 724 (2017) 1037-1045.

M. A. E 1. Baradie, A fuzzy logic model for machining data selection, Int. J. Mach. Tools Manufact. Vol 37 (1997) 1353-1372.

Ruey-Jing Lian, Bai-Fu Lin, Jyun-Han Huang, A grey prediction fuzzy controller for constant cutting force in turning, International Journal of Machine Tools \& Manufacture 45 (2005) 1047-1056.

Asif Iqbal, Ning He, Liang Li, N. U. Dar, A fuzzy expert system for optimizing parameters and predicting performance measures in hard-milling process, Expert Systems with Applications 32 (2007) 1020-1027.

M. Chandrasekaran, M. Muralidhar, C. Murali Krishna, U. S. Dixit, Application of soft computing techniques in machining performance prediction and optimization: a literature review, Int J Adv Manuf Technol 46 (2010) 445-464.

M. M. Barzani, E. Zalnezhad, A. A.D. Sarhan, Saeed Farahany, Singh Ramesh, Fuzzy Logic Based Model for Predicting Surface Roughness of Machined Al-Si-Cu-Fe Die Casting Alloy Using Different Additives-Turning, Measurement (2014).

B. Cuka, Dong-Won Kim, Fuzzy logic based tool condition monitoring for endmilling, Robotics and Computer Integrated Manufacturing (2016).

K. Venkata Rao, B.S.N. Murthy, N. Mohan Rao, Prediction of cutting tool wear, surface roughness and vibration of work piece in boring of AISI 316 steel with artificial neural network, Measurement 51 (2014), 63-70.

D. M. D’Addona, A. M. M. Sharif Ullah, D. Matarazzo, Tool-wear prediction and pattern-recognition using artificial neural network and DNA-based computing, J Intell Manuf (2015). 
Kumar, S.: Review on Optimization Techniques used for Determining Machining C...

Amir M. Khorasani, Mohammad R. S. Yazdi, Development of a dynamic surface roughness monitoring system based on artificial neural networks (ANN) in milling operation, Int J Adv Manuf Technol (2015).

B. Das, S. Roy, R.N. Rai, S.C. Saha, Study on machinability of in situ Al-4.5\%CuTiC metal matrix composite-surface finish, cutting force prediction using ANN, CIRP Journal of Manufacturing Science and Technology (2015).

C. Drouillet, J. Karandikar, C. Nath, Anne-Claire Journeaux, Mohamed El Mansori, T. Kurfess, Tool life predictions in milling using spindle power with the neural network technique, Journal of Manufacturing Processes 22 (2016) 161-168.

A. I. Azmi, R. J. T. Lin, D. Bhattacharyya, Tool wear prediction models during end milling of glass fibre-reinforced polymer composites, Int J Adv Manuf Technol 67 (2013) 701-718

Muhammad Rizal, J. A. Ghani, Mohd Zaki Nuawi, Che Hassan Che Haron, Online tool wear prediction system in the turning process using an adaptive neuro-fuzzy inference system, Applied Soft Computing 13 (2013) 1960-1968.

V. Jain, T. Raj, Tool life management of unmanned production system based on surface roughness by ANFIS, Int J Syst Assur Eng Manag (2016).

Adel T. Abbas, M. Alata, A. E. Ragab, M. M. El Rayes, E. A. El Danaf, Prediction Model of Cutting Parameters for Turning High Strength Steel Grade-H: Comparative Study of Regression Model versus ANFIS, Advances in Materials Science and Engineering Volume 2017 (2017).

Binayak Sen, Uttam Kumar Mandal, Sankar Prasad Mondal, Advancement of an intelligent system based on ANFIS for predicting machining performance parameters of Inconel 690 - A perspective of metaheuristic approach, Measurement (2017). 